Endothelial function in patients with chronic obstructive pulmonary disease: a systematic review of studies using flow mediated dilatation Peer-reviewed author version

Vaes, Anouk W.; SPRUIT, Martijn A.; THEUNIS, Jan; Goswami, Nandu; Vanfleteren, Lowie E.; Franssen, Frits M. E.; Wouters, Emiel F. M. \& DE BOEVER, Patrick (2017) Endothelial function in patients with chronic obstructive pulmonary disease: a systematic review of studies using flow mediated dilatation. In: EXPERT REVIEW OF RESPIRATORY MEDICINE, 11(12), p. 1021-1031.

DOI: $10.1080 / 17476348.2017 .1389277$

Handle: http://hdl.handle.net/1942/26393 


\section{Endothelial function in patients with chronic obstructive pulmonary disease: a systematic review of studies using flow mediated dilatation}

Anouk W. Vaes, Martijn A. Spruit, Jan Theunis, Nandu Goswami, Lowie E. Vanfleteren, Frits M.E. Franssen, Emiel F.M. Wouters \& Patrick De Boever

To cite this article: Anouk W. Vaes, Martijn A. Spruit, Jan Theunis, Nandu Goswami, Lowie E. Vanfleteren, Frits M.E. Franssen, Emiel F.M. Wouters \& Patrick De Boever (2017): Endothelial function in patients with chronic obstructive pulmonary disease: a systematic review of studies using flow mediated dilatation, Expert Review of Respiratory Medicine, DOI: 10.1080/17476348.2017.1389277

To link to this article: http://dx.doi.org/10.1080/17476348.2017.1389277

Accepted author version posted online: 05 Oct 2017.

Submit your article to this journal $₫$

Џ Article views: 1

Q View related articles $\asymp$

View Crossmark data ־ 
Publisher: Taylor \& Francis

Journal: Expert Review of Respiratory Medicine

DOI: $10.1080 / 17476348.2017 .1389277$

Original Research

Endothelial function in patients with chronic obstructive pulmonary disease: a systematic review of studies using flow mediated dilatation

Anouk W. Vaes ${ }^{* 1,2}$, Martijn A. Spruit ${ }^{1,3,4}$, Jan Theunis $^{2}$, Nandu Goswami ${ }^{5}$, Lowie E. Vanfleteren $^{1,4}$, Frits M.E. Franssen ${ }^{1,4}$, Emiel F.M. Wouters ${ }^{1,4}$, Patrick De Boever ${ }^{2,6}$

${ }^{1}$ Department of Research and Education, Ciro, Horn, Netherlands

${ }^{2}$ Environmental Risk and Health Unit, Flemish Institute for Technological Research (VITO), Mol, Belgium

${ }^{3}$ Department of Respiratory Medicine, Maastricht University Medical Centre (MUMC+), NUTRIM School of Nutrition and Translational Research in Metabolism, Maastricht, The Netherlands.

${ }^{4}$ REVAL - Rehabilitation Research Center, BIOMED - Biomedical Research Institute, Faculty of Medicine and Life Sciences, Hasselt University, Diepenbeek, Belgium.

${ }^{5}$ Department of Physiology, Medical University of Graz, Graz, Austria

${ }^{6}$ Centre for Environmental Sciences, Hasselt University, Hasselt, Belgium.

*Corresponding author:

Anouk W. Vaes

Email: anoukvaes@ciro-horn.nl 


\section{Abstract}

Background: Cardiovascular disease is an important cause of morbidity and mortality in chronic obstructive pulmonary disease (COPD). Endothelial function may be involved in the pathogenesis of cardiovascular disease. In contrast to the attention given to pulmonary endothelial dysfunction, little is known about peripheral vascular changes in COPD. Therefore, we reviewed the literature on peripheral endothelial function in COPD.

Methods: Databases were screened for studies using ultrasound-based flow-mediated dilation (FMD), the reference method for assessing peripheral endothelial function, in stable COPD patients. Pooled effect sizes were calculated using random effects model.

Results: 17 studies were identified, with a total of 1228 participants (724 COPD patients; 504 controls). Pooled analysis demonstrated an impaired endothelial-dependent FMD (-3.22\%; 95\% confidence interval ( $\mathrm{Cl})-4.74$ to $\left.-1.69 ; \mathrm{p}<0.001 ; \mathrm{I}^{2}=96 \%\right)$ and endothelial-independent FMD $\left(-2.86 \% ; 95 \% \mathrm{Cl}-5.63\right.$ to $\left.-0.09 ; \mathrm{p}=0.04 ; \mathrm{I}^{2}=83 \%\right)$ in COPD patients when compared with smoking and non-smoking controls.

Conclusion: This review provides evidence for impaired peripheral endothelial function in COPD. Since impaired endothelial function may contribute to cardiovascular morbidity, a more comprehensive cardiovascular phenotyping is considered important in COPD to address cardiovascular risk. A high frequency of cardiovascular comorbidity is observed in COPD patients, and therefore well-controlled, larger studies that investigate endothelial function in COPD patients are recommended.

Keywords: COPD, cardiovascular disease, endothelial function, flow mediated dilatation, cardiovascular risk 


\section{Introduction}

Chronic obstructive pulmonary disease (COPD), primarily a disease of airways and lungs, is now considered a complex, heterogeneous and multicomponent condition. It is increasingly recognized that cardiovascular comorbidities contribute to the severity of the disease [1]. Ischemic heart disease and peripheral vascular diseases are highly prevalent in COPD and a decrease in forced expiratory volume in 1 second $\left(\mathrm{FEV}_{1}\right)$ is associated with an increased risk of cardiovascular hospitalization and mortality [2-4]. Studies have shown a significant association between $\mathrm{FEV}_{1}$ and cardiovascular risk, independent of established cardiovascular risk factors such as sex, age, smoking status, serum cholesterol levels, education and social class $[5,6]$. Changes in vascular endothelial function accompany the increased cardiovascular risk in COPD $[7,8]$.

The endothelium plays a major role in the regulation of vascular tone, controlling tissue blood flow and inflammatory responses, and maintaining blood fluidity. Normal endothelial function ensures a balanced response between vasoconstrictive and vasodilatory stimuli, with nitric oxide (NO) as a primary mediator $[9,10]$. An imbalance in NO production is as a major mechanism of endothelial dysfunction, which is a progenitor of atherosclerosis [10]. Atherosclerosis and calcification of the large arteries further decrease vascular compliance. Such structural changes in the vessel wall explain the increased arterial stiffness observed in patients with COPD [11]. Endothelial dysfunction is an early, potentially reversible precursor of vascular disease [9]. Risk factors for endothelial dysfunction have been identified, including smoking, aging, family history of early cardiovascular diseases, elevated triglycerides, elevated low-density lipoprotein cholesterol and reduced high-density lipoprotein cholesterol, hyperglycemia, hypertension, physical inactivity, obesity, and presence of systemic inflammation, [9, 10,12]. Monitoring endothelial function in patients with COPD may be valuable for risk stratification and identification of future cardiovascular pathologies and disease progression.

Pulmonary vascular endothelial dysfunction is well established in patients with COPD [13, 14]. It was initially shown in patients with end-stage COPD, but nowadays, it is known that pulmonary vascular endothelial dysfunction is already present in patients with mild COPD 
[13]. It has been demonstrated that pulmonary vascular endothelial dysfunction contributes directly to the progression of COPD [15].

In contrast to the attention given to endothelial dysfunction in the pulmonary vessels, changes in other vascular beds of patients with COPD have received less attention. The reference method for noninvasive assessment of peripheral endothelial function is flowmediated dilatation (FMD) using ultrasound. FMD measures the change in brachial artery diameter after a five-minute occlusion with a blood pressure cuff $[16,17]$. FMD is defined as the percentage change in brachial artery diameter from baseline to maximum increase and measures the ability of conduit arteries to respond with endothelial NO release during reactive hyperemia [16]. A FMD level of less than $4.1 \%$ is strongly correlated with vascular damage [18]. In addition, endothelium independent function can be measured using an exogenous NO donor, such as nitroglycerin spray or sublingual tablets, and is commonly assessed in combination with FMD. This protocol allows to determine whether changes in vasodilation are attributed to the endothelial or vascular smooth muscle layers $[16,17]$. Although FMD does not measure vascular function in the coronary circulation directly, it has predictive power for future cardiovascular events $[17,19]$.

In this paper, we systematically reviewed the scientific literature on peripheral endothelial function assessed by FMD using ultrasound in stable patients with COPD. In addition, we assessed differences in endothelial function between patients with COPD and non-COPD control subjects.

\section{Methods}

\subsection{Data sources and searches}

A computerized literature search was performed in Medline/PubMed, Web of Knowledge and Embase between March and August 2017. The reader is referred to the supplementary file for the search strings used to identify relevant articles. The search was not limited by year of publication. In total, 104 articles were retrieved.

\subsection{Study selection}

Studies that met the following criteria were included: 1) Participants: stable patients with COPD; 2) Outcome: extrapulmonary endothelial function; 3) Methods: noninvasive 
assessment of endothelial function using FMD. Titles and abstracts were screened for inclusion criteria and potentially eligible articles were retrieved. References from these articles and previous reviews were also scanned for additional relevant articles. Non-English language articles, review articles, editorials, qualitative studies, methodology studies and congress abstracts were excluded. In addition, studies investigating pulmonary endothelial function were excluded.

\subsection{Screening, data extraction and quality assessment}

Study screening and data extraction were performed by two independent reviewers. Details of study designs and relevant results were obtained in a predesigned data abstraction form. For each study, authors, journal, year of publication, participant characteristics (sex, age, disease severity), methods to assess endothelial function, outcome parameters, and main outcomes were recorded. If necessary, authors of included study were contacted directly to request additional data.

The methodological quality of studies included in the meta-analyses was assessed using the Newcastle-Ottowa Scale (NOS), which is developed for quality assessment of nonrandomized studies. The NOS contains eight items categorized into three domains: methods of selection of study group, comparability of the study group and ascertainment of the outcome of interest. Scores range from 0 to 9, where a higher score indicates a better methodological quality.

\subsection{Statistics}

Meta-analytic techniques were conducted in RevMan version 5.3 (Copenhagen: The Nordic Cochrane Centre, The Cochrane Collaboration, 2014). A funnel plot was used to check for publication bias. Egger's regression test and Begg and Mazumdar rank correlation test were used to assess publication bias, in which $p<0.10$ is considered statistically significant [20].

The $\mathrm{I}^{2}$ was calculated for each model to determine the proportion of observed variance due to heterogeneity. Values of $25 \%, 50 \%$ and $75 \%$ were used as boundary limits for low, moderate, or high heterogeneity, respectively [21]. In the case that significant betweenstudy heterogeneity was identified, random effects meta-analysis was used to calculate pooled effect estimates. All studies reporting differences in endothelial function between patients with COPD and non-COPD control subjects were included in the models. If a study 
included more than one control group (e.g. smoking and non-smoking non-COPD controls), each comparison with the COPD group was entered in the model.

To assess the possible effect of important demographic and clinical variables (including gender, age, disease severity, BMI, smoking history, cardiovascular comorbidities) on differences across studies, we performed meta-regression analyses with Comprehensive Meta-analysis [Version 3, Biostat, Englewood, USA).

\section{Results}

Seventeen original studies used ultrasound-based FMD to determine endothelial function in patients with COPD (Figure 1, Table 1 and 2) [22-38]. A total number of 1228 participants was evaluated: 724 patients with a spirometry-based diagnosis of COPD (71\% men; mean age: $65 \pm 5$ years; body mass index (BMI): $27 \pm 2 \mathrm{~kg} / \mathrm{m}^{2}$ ) and 504 controls ( $56 \%$ men; mean age: $62 \pm 8$ years; BMI: $27 \pm 2 \mathrm{~kg} / \mathrm{m}^{2}$ ) (Table 1 ).

A pooled analysis to study the difference in endothelium-dependent FMD between stable patients with COPD and healthy controls included ten studies [23, 26-33, 39]. Methodological quality of these studies ranged from 5 to 9 points on the NOS (Supplemental Table 1). Four studies from the total of 17 were not included in the meta-analyses because the studies only measured patients with COPD and did not include a control group [24, 25, $34,36]$; three of these focused on determinants of endothelial function $[24,25,34]$ and one studied the effect of lung volume reduction surgery on endothelial function in patients with COPD [36]. Additionally, three studies were excluded from the analysis since percentage mean change in brachial artery diameter and standard deviation were not available, even after contacting the corresponding authors [22, 37, 38].

Pooled analysis showed that patients with $\operatorname{COPD}(n=426)$ had a significantly lower increase in FMD, compared to controls ( $n=310)$ (FMD (\%): -3.22 ; 95\% confidence interval $(\mathrm{Cl})-4.74$ to 1.69; $p<0.001$; Figure 2). FMD ranged from -0.6 to $14.2 \%$ in patients with COPD and from 4.3 to $15.6 \%$ in controls. Heterogeneity was high $\left(1^{2}=96 \%\right)$ and was not reduced by exclusion of individual studies. Asymmetry in the funnel plot indicates that the possibility of publication bias could not be excluded, in addition to the fact that the included studies were all of small size (Figure A1 of supplementary file). Though, despite this apparent asymmetry, both the 
Egger's regression test and Begg and Mazumdar rank correlation test were not statistically significant (Supplementary file).

Meta-regression identified that age $(Z=3.97 ; p<0.001), \mathrm{FEV}_{1}(Z=4.52 ; p<0.001)$, smoking status $(Z=-2.55 ; p=0.01)$ and pack-years of smoking $(Z=-4.29 ; p<0.001)$ were significant associated with FMD. Subgroup analysis comparing endothelial function of COPD patients with smoking and non-smoking controls are included in the supplementary file.

Studies without a healthy control group showed a higher FMD in polycythemic patients with COPD (patients with an increased red blood cell volume) compared to normocythemic patients $(3.97 \pm 0.39$ vs. $2.85 \pm 0.25 \%$, respectively, $P<0.02)$ [24]. Significant negative associations between FMD and severity of airflow limitation (post-bronchodilator FEV1 \% pred.)[25] and altered glucose metabolism [34] were observed. Urban et al. showed a significant decrease in FMD over a 12-month period (from 13.5\% (10.5-14.9\%) at baseline to 9.8\% (6.4-11.8\%) at follow up; $\mathrm{p}=0.002)$, which were related to changes in $\mathrm{FEV}_{1}$ and insulin resistance [34]. Furthermore, Clarenbach et al. showed that COPD patients undergoing lung volume reduction surgery had a significant improvement in FMD compared to non-surgical control patients after 3 months $(2.4 \pm 1.3$ to $4.8 \pm 1.7$ in the intervention group versus $2.0 \pm 0.9$ to $1.5 \pm 1.0$ in the control group; effect: $+2.9 \% ; 95 \% \mathrm{Cl}+2.1$ to $+3.6 \%$; $\mathrm{P}<0.001$ ), providing evidence for a link between lung function impairment and vascular disease in patients with COPD [36].

Seven studies determined the endothelium-independent vasodilation after sublingual nitroglycerin administration (nitroglycerin-mediated dilation, NMD) [28, 29, 31-34]. Urban et al. only included patients with COPD and no control subjects and was not considered for pooled analysis [34]. Whereas data showed a decrease in percentage of FMD over a 12 month period $(13.5 \%(10.5-14.9 \%)$ versus $9.8 \%(6.4-11.8 \%) ; p=0.002)$, no significant difference was found in percentage of NMD between baseline and follow-up (22.1\% (19.9$28.0 \%$ ) versus $19.9 \%(16.0-25.0 \%) ; p=0.133)$ [34]. Pooled analysis of six studies showed that patients with COPD $(n=235)$ had a significantly lower NMD compared to controls $(n=147)$ (NMD (\%): -2.86; 95\% confidence interval -5.63 to $-0.09 ; p=0.04$; Figure 3) [28, 29, 31-33, 39]. Heterogeneity was high $\left(\mathrm{I}^{2}=83 \%\right)$ and was not reduced by exclusion of individual studies. 
Funnel plot did not suggest publication bias (Figure A2 of supplementary file), which was confirmed by the Egger's regression test and Begg and Mazumdar rank correlation test (Supplementary file).

Meta-regression identified that age $(Z=2.07 ; p=0.04), F E V_{1}(Z=2.51 ; p=0.01)$ and smoking status ( $Z=-3.79 ; p<0.001)$ were significant associated with NMD.

\section{Discussion}

This is the first systematic review of the assessment of peripheral endothelial function using ultrasound-based FMD in patients with COPD, indicating that patients with COPD show a reduced vasodilatory response compared with controls without COPD.

Pooled analyses showed differences in both FMD and NMD in patients with COPD compared with control subjects, with a higher difference in endothelial-dependent compared to endothelial-independent dilation (mean difference of -3.22 and -2.86 , respectively; Figures 2 and 3). Endothelial-dependent and endothelial-independent vasodilation reflect different physiological responses. Endothelial-dependent dilation is a marker of endothelial ability to produce and release NO in response to a physiological stimulus such as increased flow and related shear stress, whereas endothelial-independent dilation depends on the dynamic tone of the vascular smooth muscle cells [40]. The results suggest that endothelial function changes in patients with COPD are primarily induced by defects at the endothelium level.

The studies that were reviewed suggest that the majority of COPD patients have reduced endothelial function in the peripheral circulation. Studies demonstrated significant variability in FMD and not all studies found a difference in endothelial function between patients with COPD and control subjects [26, 27, 29]. Difference between included subjects, regarding age, COPD severity, and smoking may be a possible explanation for this. Indeed, we have identified that age, $\mathrm{FEV}_{1}$ and smoking were significant associated with FMD. Earlier studies also demonstrated that peripheral endothelial dysfunction is associated with the severity of COPD $[22,25,28,32]$. Furthermore COPD exacerbations seem to alter endothelial function, probably owing to decreased levels of advanced glycation end-products, and increased arterial carbon dioxide tension, oxidative stress and systemic inflammation [27, 31, 33, 35], though, impaired endothelial function was also present in stable patients $[23,28,32]$. In 
addition, from earlier population-based studies it is already known that smokers have an impaired endothelial function compared to non-smokers or ex-smokers, and that smoking intensity (pack- years of smoking) is independently associated with endothelial function [41, 42]. However, in patients with COPD, endothelial dysfunction seems to be independent of smoking status and smoking history $[22,25,28,32]$, indicating that other aspects of COPD may cause impaired endothelial function. Indeed, Eickhoff et al. and Pizzaro et al. demonstrated that inflammatory markers were increased in COPD and that these markers were independent predictors of $\operatorname{FMD}[28,38]$. A low sample size of several studies [7, 29, 31] probably also resulted in limited power to detect significant effects. Furthermore, several studies did not report data on the presence and severity of emphysema $[23-34,37,38]$ and arterial blood gases $[22,23,26,30,32,33,36,37]$, which are known to potentially affect endothelial function [22, 25, 27]. Finally, one study used upper arm occlusion [28], while others used forearm cuff occlusion [22, 24-27, 29, 32, 36]. When the cuff is placed on the upper part of the arm, reactive hyperemia typically elicits a greater percentage of change in diameter compared with the change produced by placement of the cuff on the forearm. This may be due to a greater flow stimulus resulting from recruitment of more resistance vessels or to direct effects of ischemia on the brachial artery [43].

Other noninvasive assessment methods for peripheral endothelial function showed mixed results. Using venous occlusion plethysmography, Yang et al. demonstrated a significantly lower endothelium-dependent vasodilation in patients with COPD compared to matched controls (maximal dilatation $552 \pm 103 \%$ vs $1314 \pm 191 \%$, respectively; $p=0.005$ ) [44], whilst Maclay et al. did not find a difference in endothelium-dependent and endotheliumindependent vasodilation between COPD patients and controls using the same technique [7]. In addition, Minet et al. showed that endothelial dysfunction assessed using digital peripheral arterial tonometry (Endo-PAT 2000) occurred in half of the studied COPD patients and amplified during exacerbation [45].

Today, noninvasive assessment of endothelial function is mainly used for research purposes assessing disease mechanisms. However, due to the low burden of the procedures, they represent a remarkable potential for clinical practice to improve patient risk stratification in primary and secondary prevention, the evaluation of vascular responses to pharmacological 
and non-pharmacological intervention, and longitudinal patient monitoring [17, 46]. Noninvasive assessment techniques of endothelial function are predictive for cardiovascular events in patients with cardiovascular diseases, subjects with an increased cardiovascular risk and elderly subjects [19], but currently, no data are available for patients with COPD.

Given the predictive value of endothelial dysfunction, preservation or recovery of endothelial function can be an important therapeutic aim in the prevention of cardiovascular diseases [47-49]. Studies evaluating interventions to improve endothelial function in patients with COPD are scarce $[29,36,50]$. Endothelial dysfunction is a reversible disorder and several pharmacological interventions that aimed at reducing cardiovascular risk have a beneficial effect on endothelial function $[17,46]$. Neukamm et al. showed that short-term statin therapy resulted in improved endothelium-dependent vascular function, but only in a subgroup of COPD patients with high concentrations of hsCRP [50]. Furthermore, antiplatelet medication is associated with an improvement of endothelial function in patients with stable coronary artery disease and concomitant COPD patients[51], In addition, an earlier review demonstrated that both anti-hypertensive drugs and beta blockers are able to significantly improve endothelial function in patients with cardiovascular disease or increased cardiovascular risk [52].

In addition, exercise and increased physical activity level are important to reduce cardiovascular risk and improve endothelial function in healthy subjects and patients suffering from heart failure, diabetes, and coronary artery disease [53]. Although, it has been shown that daily physical activity level and aerobic exercises seem to be an important determinant of endothelial function in patients with COPD [25], only one study investigated the possible effect of an exercise program on endothelial function [39]. Gelinas et al. did not found an improvement in endothelial function after an aerobic exercise program. This was probably due to the relatively low absolute training intensities and cardiac outputs, preventing patients to generate adequate shear stress to enhance endothelial function and/or structural changes [39].

Furthermore, smoking cessation has a beneficial effect on endothelial function in healthy subjects, though, this effect was not present in ex-smokers with COPD [42, 54, 55]. 
Considering that oxidative stress is the main pathophysiologic mechanism leading to impaired NO bioavailability and endothelial dysfunction, dietary interventions with foods rich of antioxidants have attracted a lot of attention $[9,17,56]$. In COPD, only the effect of vitamin C was investigated, showing an improved endothelial function after vitamin C infusion [29].

We have performed for the first time a review of peripheral endothelial function, as assessed with FMD, in patients with COPD that are suffering significantly from cardiovascular comorbidity. Taking into account that FMD is reference method for measuring vascular function, our review surprisingly found that no large systematic studies have been conducted in patients with COPD. The available data suggest that endothelial function is compromised in this patient population. Our workflow selected 17 studies, but only 10 studies could be included in the meta-analysis. Furthermore, some of the authors did not reply to the request for additional data $[22,37,38]$. The heterogeneity of the studies included in the pooled analysis was high $\left(\mathrm{I}^{2}=79-95 \%\right)$ and was not reduced after exclusion of individual studies. The high heterogeneity can be explained by differences in included patients and controls. Although patients and controls were matched in the individual studies, there was considerable difference between the studies regarding age, sex distribution, severity of COPD, and smoking or non-smoking controls. This may potentially influence the level endothelial dysfunction. In this respect, one should keep in mind that about a quarter of meta-analyses have $\mathrm{I}^{2}$ values over $50 \%$, indicating that substantial heterogeneity is common, especially in meta-analyses of observational studies [21]. The possibility of publication bias could not be excluded due to the asymmetry in the funnel plot comparing studies using ultrasound-based flow-mediated dilation of the brachial artery. Additional sources may be responsible for funnel plot asymmetry, including poor methodological quality of small studies, true heterogeneity and chance [57].

\section{Conclusion}

This review provides evidence of impaired peripheral endothelial function in patients with COPD. However, studies demonstrated significant variability, and therefore, scientific consensus has yet to be reached regarding peripheral endothelial function in COPD. Since endothelial dysfunction can contribute to cardiovascular morbidity, vascular assessments 
can be valuable for better phenotyping patients with COPD and addressing their cardiovascular risk. Considering the high frequency of cardiovascular comorbidity in COPD patients, well-controlled and larger studies, adjusting for traditional cardiovascular risk factors such as age, smoking, body mass index, hypertension, diabetes and dyslipidemia, are recommended to further clarify the association between peripheral endothelial dysfunction and COPD.

Key issues:

- This review provides evidence that patients with COPD can have impaired peripheral endothelial function compared to smoking and nonsmoking controls.

- Both endothelial-dependent and endothelial-independent dilation are impaired in patients with COPD.

- Age, severity of airflow obstruction, smoking status and pack-years of smoking are significant associated with impaired peripheral endothelial function in COPD.

- Since peripheral endothelial dysfunction may contribute to cardiovascular morbidity, a more comprehensive cardiovascular assessment is considered important for better phenotyping patients with COPD to address their cardiovascular risk.

- Considering the high frequency of cardiovascular comorbidity in COPD patients, wellcontrolled and larger studies that investigate peripheral endothelial function are recommended in patients with COPD.

\section{Funding}

This manuscript has not received any funding.

\section{Declaration of interest}

MA Spruit has received remuneration for consultancy and/or lectures from Boehringer Ingelheim and GlaxoSmithKline, outside of the submitted work. The authors have no other relevant affiliations or financial involvement with any organization or entity with a financial interest in or financial conflict with the subject matter or materials discussed in the manuscript apart from those disclosed. 


\section{Author contributions}

AWV, PDB and MAS developed the systematic review protocol and search strategy. AWV and PDB performed the electronic database searches, screened articles for inclusion and completed data extraction. All authors contributed to critical revision of the manuscript for important intellectual content and approved the final version. 


\section{References}

Reference annotations

* Of interest

** Of considerable interest

1. Vanfleteren LE, Spruit MA, Groenen M, et al. Clusters of comorbidities based on validated objective measurements and systemic inflammation in patients with chronic obstructive pulmonary disease. Am J Respir Crit Care Med. 2013;187(7):728-35.

*This study provides evidence that cardiovascular comorbidities are frequently present in COPD and therefore, a more comprehensive cardiovascular phenotyping is considered important in COPD to address cardiovascular risk.

2. Anthonisen NR, Connett JE, Enright PL, et al. Hospitalizations and mortality in the Lung Health Study. Am J Respir Crit Care Med. 2002;166(3):333-9.

3. Hole DJ, Watt GC, Davey-Smith G, et al. Impaired lung function and mortality risk in men and women: findings from the Renfrew and Paisley prospective population study. Bmj. 1996;313(7059):711-5; discussion 5-6.

4. Sin DD, Wu L, Man SF. The relationship between reduced lung function and cardiovascular mortality: a population-based study and a systematic review of the literature. Chest. 2005;127(6):1952-9.

5. Maclay JD, McAllister DA, Macnee W. Cardiovascular risk in chronic obstructive pulmonary disease. Respirology. 2007;12(5):634-41.

6. MacNee W, Maclay J, McAllister D. Cardiovascular injury and repair in chronic obstructive pulmonary disease. Proceedings of the American Thoracic Society. 2008;5(8):824-33.

7. Maclay JD, McAllister DA, Mills NL, et al. Vascular dysfunction in chronic obstructive pulmonary disease. Am J Respir Crit Care Med. 2009;180(6):513-20.

8. Sabit R, Shale DJ. Vascular structure and function in chronic obstructive pulmonary disease: a chicken and egg issue? Am J Respir Crit Care Med. 2007;176(12):1175-6.

9. Hadi HA, Carr CS, Al Suwaidi J. Endothelial dysfunction: cardiovascular risk factors, therapy, and outcome. Vasc Health Risk Manag. 2005;1(3):183-98.

*Providing evidence that endothelial dysfunction is an precursor of cardiovascular disease.

10. Widmer RJ, Lerman A. Endothelial dysfunction and cardiovascular disease. Glob Cardiol Sci Pract. 2014;2014(3):291-308.

11. Mills NL, Miller JJ, Anand A, et al. Increased arterial stiffness in patients with chronic obstructive pulmonary disease: a mechanism for increased cardiovascular risk. Thorax. 2008;63(4):306-11.

12. Sena CM, Pereira AM, Seica R. Endothelial dysfunction - a major mediator of diabetic vascular disease. Biochim Biophys Acta. 2013;1832(12):2216-31.

13. Peinado VI, Pizarro S, Barbera JA. Pulmonary vascular involvement in COPD. Chest. 2008;134(4):808-14.

14. Peinado VI, Barbera JA, Ramirez J, et al. Endothelial dysfunction in pulmonary arteries of patients with mild COPD. Am J Physiol. 1998;274(6 Pt 1):L908-13.

15. Green CE, Turner AM. The role of the endothelium in asthma and chronic obstructive pulmonary disease (COPD). Respir Res. 2017;18(1):20.

16. Celermajer DS, Sorensen KE, Gooch VM, et al. Non-invasive detection of endothelial dysfunction in children and adults at risk of atherosclerosis. Lancet. 1992;340(8828):1111-5. 
*Study describes the noninvasive assessment of peripheral endothelial function by flowmediated dilatation (FMD), which is used as method in our review.

17. Flammer AJ, Anderson T, Celermajer DS, et al. The assessment of endothelial function: from research into clinical practice. Circulation. 2012;126(6):753-67.

*Gives an important overview of methods for noninvasive assessment of endothelial function and their use in research and clinical practice.

18. Halcox JP, Donald AE, Ellins $E$, et al. Endothelial function predicts progression of carotid intima-media thickness. Circulation. 2009;119(7):1005-12.

19. Matsuzawa Y, Kwon TG, Lennon RJ, et al. Prognostic Value of Flow-Mediated Vasodilation in Brachial Artery and Fingertip Artery for Cardiovascular Events: A Systematic Review and Meta-Analysis. J Am Heart Assoc. 2015;4(11).

* Gives an overview of the association between peripheral endothelial dysfunction measured by FMD and cardiovascular events in elderly and patients with increased cardiovascular risk.

20. Sterne JA, Egger M, Smith GD. Systematic reviews in health care: Investigating and dealing with publication and other biases in meta-analysis. Bmj. 2001;323(7304):101-5.

21. Higgins JP, Thompson SG, Deeks JJ, et al. Measuring inconsistency in meta-analyses. Bmj. 2003;327(7414):557-60.

22. Barr RG, Mesia-Vela S, Austin JH, et al. Impaired flow-mediated dilation is associated with low pulmonary function and emphysema in ex-smokers: the Emphysema and Cancer Action Project (EMCAP) Study. Am J Respir Crit Care Med. 2007;176(12):1200-7.

*The first published study describing endothelial dysfunction, as assessed with FMD, in COPD.

23. Blum A, Simsolo C, Sirchan R. Vascular responsiveness in patients with Chronic Obstructive Pulmonary Disease (COPD). Eur J Intern Med. 2014;25(4):370-3.

24. Boyer L, Chaar V, Pelle G, et al. Effects of polycythemia on systemic endothelial function in chronic hypoxic lung disease. J Appl Physiol (1985). 2011;110(5):1196-203.

25. Clarenbach CF, Senn O, Sievi NA, et al. Determinants of endothelial function in patients with COPD. Eur Respir J. 2013;42(5):1194-204.

26. Costanzo L, Pedone C, Battistoni F, et al. Relationship between FEV and arterial stiffness in elderly people with chronic obstructive pulmonary disease. Aging Clin Exp Res. 2016.

27. de Matthaeis A, Greco A, Dagostino MP, et al. Effects of hypercapnia on peripheral vascular reactivity in elderly patients with acute exacerbation of chronic obstructive pulmonary disease. Clin Interv Aging. 2014;9:871-8.

28. Eickhoff $P$, Valipour $A$, Kiss $D$, et al. Determinants of systemic vascular function in patients with stable chronic obstructive pulmonary disease. Am J Respir Crit Care Med. 2008;178(12):1211-8.

29. Hartmann SE, Waltz X, Leigh R, et al. Blood Flow during Handgrip Exercise in COPD: Effect of Vitamin C. Med Sci Sports Exerc. 2016;48(2):200-9.

30. Ives SJ, Harris RA, Witman MA, et al. Vascular dysfunction and chronic obstructive pulmonary disease: the role of redox balance. Hypertension. 2014;63(3):459-67.

31. Marchetti N, Ciccolella DE, Jacobs MR, et al. Hospitalized acute exacerbation of COPD impairs flow and nitroglycerin-mediated peripheral vascular dilation. Copd. 2011;8(2):60-5.

32. Moro L, Pedone C, Scarlata S, et al. Endothelial dysfunction in chronic obstructive pulmonary disease. Angiology. 2008;59(3):357-64. 
33. Ozben B, Eryuksel E, Tanrikulu AM, et al. Acute exacerbation impairs endothelial function in patients with chronic obstructive pulmonary disease. Turk Kardiyol Dern Ars. 2010;38(1):1-7.

34. Urban $\mathrm{MH}, \mathrm{Ay} \mathrm{L}$, Funk $\mathrm{GC}$, et al. Insulin resistance may contribute to vascular dysfunction in patients with chronic obstructive pulmonary disease. Wien Klin Wochenschr. 2014;126(3-4):106-12.

35. Urban $\mathrm{MH}$, Valipour $\mathrm{A}$, Kiss $\mathrm{D}$, et al. Soluble receptor of advanced glycation endproducts and endothelial dysfunction in COPD. Respir Med. 2014;108(6):891-7.

36. Clarenbach CF, Sievi NA, Brock $M$, et al. Lung Volume Reduction Surgery and Improvement of Endothelial Function and Blood Pressure in Patients with Chronic Obstructive Pulmonary Disease. A Randomized Controlled Trial. Am J Respir Crit Care Med. 2015;192(3):307-14.

37. Kuzubova NA, Chukhlovin AB, Morozova EB, et al. Common intronic D variant of ACE gene is associated with endothelial dysfunction in COPD. Respir Med. 2013;107(8):1217-21.

38. Pizarro S, Garcia-Lucio J, Peinado VI, et al. Circulating progenitor cells and vascular dysfunction in chronic obstructive pulmonary disease. PLoS One. 2014;9(8):e106163.

39. Gelinas JC, Lewis NC, Harper MI, et al. Aerobic exercise training does not alter vascular structure and function in chronic obstructive pulmonary disease. Exp Physiol. 2017.

40. Esper RJ, Nordaby RA, Vilarino JO, et al. Endothelial dysfunction: a comprehensive appraisal. Cardiovasc Diabetol. 2006;5:4.

41. Celermajer DS, Sorensen KE, Georgakopoulos D, et al. Cigarette smoking is associated with dose-related and potentially reversible impairment of endothelium-dependent dilation in healthy young adults. Circulation. 1993;88(5 Pt 1):2149-55.

42. Johnson HM, Gossett LK, Piper ME, et al. Effects of smoking and smoking cessation on endothelial function: 1-year outcomes from a randomized clinical trial. J Am Coll Cardiol. 2010;55(18):1988-95.

43. Corretti MC, Anderson TJ, Benjamin EJ, et al. Guidelines for the ultrasound assessment of endothelial-dependent flow-mediated vasodilation of the brachial artery: a report of the International Brachial Artery Reactivity Task Force. J Am Coll Cardiol. 2002;39(2):257-65.

44. Yang L, Cheriyan J, Gutterman DD, et al. Mechanisms of Vascular Dysfunction in COPD and Effects of a Novel Soluble Epoxide Hydrolase Inhibitor in Smokers. Chest. 2017;151(3):555-63.

45. Minet C, Vivodtzev I, Tamisier R, et al. Reduced six-minute walking distance, high fatfree-mass index and hypercapnia are associated with endothelial dysfunction in COPD. Respir Physiol Neurobiol. 2012;183(2):128-34.

46. Arrebola-Moreno AL, Laclaustra M, Kaski JC. Noninvasive assessment of endothelial function in clinical practice. Rev Esp Cardiol (Engl Ed). 2012;65(1):80-90.

47. Yeboah J, Folsom AR, Burke GL, et al. Predictive value of brachial flow-mediated dilation for incident cardiovascular events in a population-based study: the multi-ethnic study of atherosclerosis. Circulation. 2009;120(6):502-9.

48. Kuvin JT, Patel AR, Sliney KA, et al. Peripheral vascular endothelial function testing as a noninvasive indicator of coronary artery disease. J Am Coll Cardiol. 2001;38(7):1843-9.

49. Ras RT, Streppel MT, Draijer R, et al. Flow-mediated dilation and cardiovascular risk prediction: a systematic review with meta-analysis. Int J Cardiol. 2013;168(1):344-51. 
50. Neukamm A, Hoiseth AD, Einvik G, et al. Rosuvastatin treatment in stable chronic obstructive pulmonary disease (RODEO): a randomized controlled trial. J Intern Med. 2015;278(1):59-67.

51. Campo G, Vieceli Dalla Sega F, Pavasini R, et al. Biological effects of ticagrelor over clopidogrel in patients with stable coronary artery disease and chronic obstructive pulmonary disease. Thrombosis and haemostasis. 2017;117(6):1208-16.

52. Peller $M$, Ozieranski K, Balsam $P$, et al. Influence of beta-blockers on endothelial function: A meta-analysis of randomized controlled trials. Cardiology journal. 2015;22(6):708-16.

53. Yung LM, Laher I, Yao X, et al. Exercise, vascular wall and cardiovascular diseases: an update (part 2). Sports Med. 2009;39(1):45-63.

54. Mendes ES, Campos MA, Wanner A. Airway blood flow reactivity in healthy smokers and in ex-smokers with or without COPD. Chest. 2006;129(4):893-8.

55. Wanner A, Campos MA, Mendes E. Airway blood flow reactivity in smokers. Pulm Pharmacol Ther. 2007;20(2):126-9.

56. Versari D, Daghini E, Virdis A, et al. Endothelial dysfunction as a target for prevention of cardiovascular disease. Diabetes Care. 2009;32 Suppl 2:S314-21.

57. Sterne JA, Sutton AJ, Ioannidis JP, et al. Recommendations for examining and interpreting funnel plot asymmetry in meta-analyses of randomised controlled trials. Bmj. 2011;343:d4002. 
Table 1: Subject characteristics

\begin{tabular}{|c|c|c|c|c|c|c|c|c|c|c|c|}
\hline \multirow[t]{2}{*}{ Authors } & \multirow[t]{2}{*}{ Population } & \multirow[t]{2}{*}{$\mathrm{N}$} & \multirow{2}{*}{$\begin{array}{l}\text { Males } \\
(\%)\end{array}$} & \multirow{2}{*}{$\begin{array}{l}\text { Age } \\
\text { (years) }\end{array}$} & \multirow{2}{*}{ COPD diagnosis } & \multirow[t]{2}{*}{ COPD severity } & \multirow{2}{*}{$\begin{array}{l}\mathrm{BMI} \\
\left(\mathrm{kg} / \mathrm{m}^{2}\right)\end{array}$} & \multirow[t]{2}{*}{ Smoking status } & \multicolumn{3}{|c|}{ Comorbidities (\%) } \\
\hline & & & & & & & & & 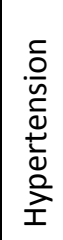 & $\overline{\bar{\Sigma}}$ & 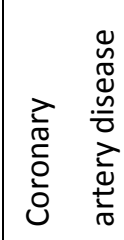 \\
\hline $\begin{array}{lll}\text { Barr et al. } \\
\text { [22] }\end{array}$ & Former smokers & 107 & 54 & $71 \pm 5$ & $\begin{array}{l}\text { post-bronchodilator FEV1/FVC } \\
\text { ratio }<0.7\end{array}$ & $\begin{array}{|ll|}\text { No: } & 60 \% \\
\text { GOLDI: } & 11 \% \\
\text { GOLDII: } & 20 \% \\
\text { GOLDIII/IV: } 9 \% & \\
\end{array}$ & $28 \pm 4$ & \begin{tabular}{ll|}
$48 \pm 26$ & pack- \\
years &
\end{tabular} & 46 & 12 & 3 \\
\hline \multirow[t]{2}{*}{$\begin{array}{l}\text { Blum et al. } \\
\text { [23] }\end{array}$} & COPD patients & 23 & 100 & $64 \pm 8$ & $\begin{array}{l}\text { GOLD criteria of } \text { COPD } \\
(\mathrm{FEV} 1 \% / \mathrm{FVC}<0.7)\end{array}$ & FEV $_{1}: 45 \pm 15 \%$ pred & $26 \pm 5$ & $100 \%$ smokers & 65 & 30 & 26 \\
\hline & Controls & 22 & 54 & $45 \pm 12$ & & & $25 \pm 4$ & $0 \%$ smokers & - & - & - \\
\hline \multirow[t]{2}{*}{$\begin{array}{ll}\text { Boyer et } \\
\text { al.[24] }\end{array}$} & $\begin{array}{l}\text { Polycythemic } \\
\text { COPD patients }\end{array}$ & 15 & 100 & $59 \pm 3$ & $\begin{array}{l}\text { evidence of chronic airflow } \\
\text { limitation on standard } \\
\text { pulmonary function tests }\end{array}$ & $\mathrm{FEV}_{1}: 45 \pm 5 \%$ pred & $32 \pm 2$ & $58 \pm 5$ pack-years & 23 & 8 & - \\
\hline & $\begin{array}{l}\text { Normocythemic } \\
\text { COPD patients }\end{array}$ & 13 & 92 & $63 \pm 2$ & & $\mathrm{FEV}_{1}: 36 \pm 4$ \%pred & $26 \pm 2$ & $52 \pm 7$ pack-years & 20 & 7 & - \\
\hline $\begin{array}{l}\text { Clarenbach et } \\
\text { al.[25] }\end{array}$ & COPD patients & 106 & 66 & $61 \pm 8$ & $\begin{array}{l}\text { objectively confirmed COPD } \\
\text { according to GOLD guidelines }\end{array}$ & $\begin{array}{l}\text { FEV }_{1}: 45 \pm 22 \% \text { pred } \\
\text { GOLD I/II: } n=38 \\
\text { GOLD III: } n=26 \\
\text { GOLD IV: } n=42\end{array}$ & $27 \pm 7$ & $\begin{array}{l}20 \% \text { smokers; } \\
40 \pm 24 \quad \text { pack- } \\
\text { years }\end{array}$ & 42 & 10 & 19 \\
\hline
\end{tabular}




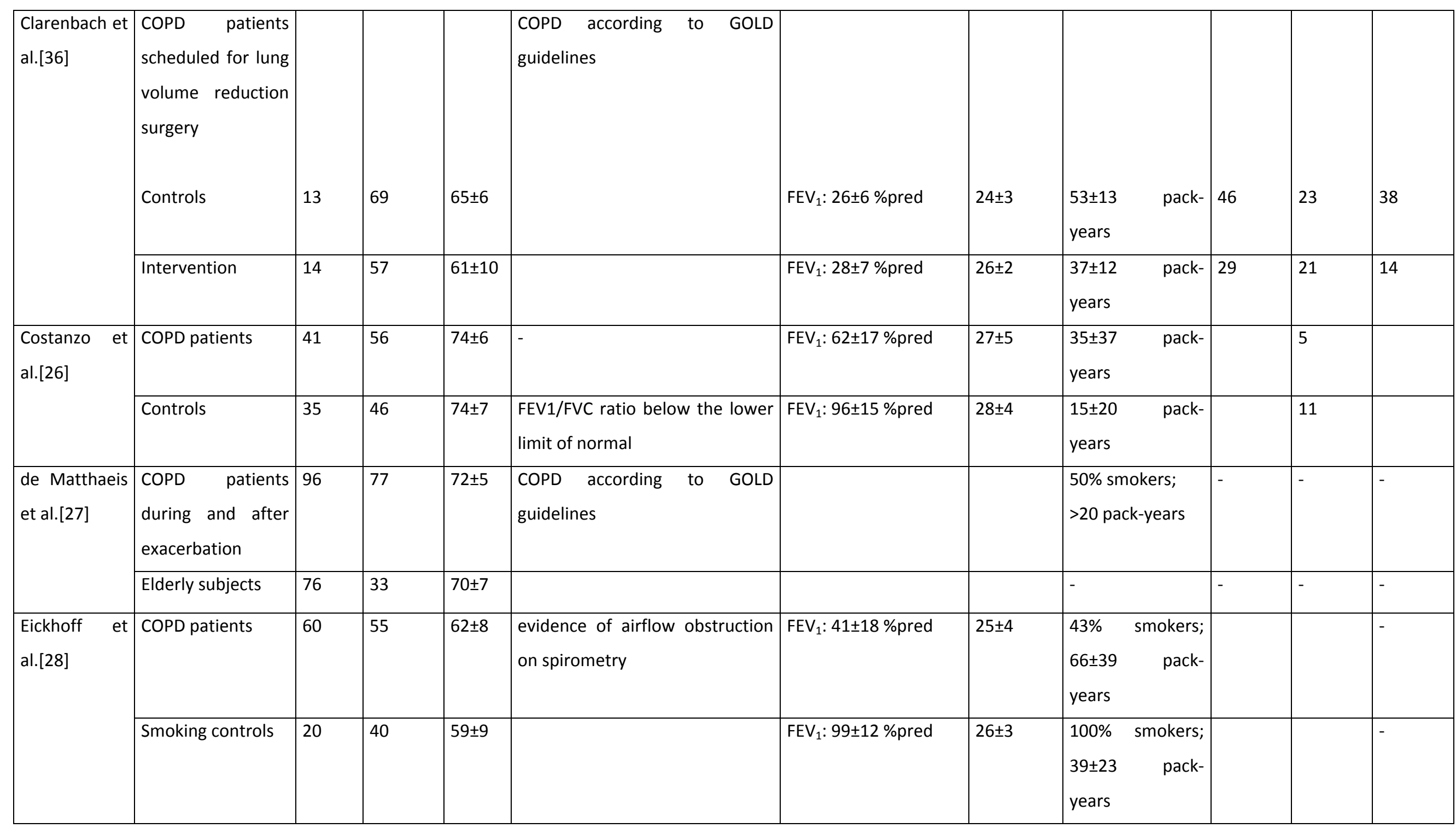




\begin{tabular}{|c|c|c|c|c|c|c|c|c|c|c|c|}
\hline & $\begin{array}{l}\text { Nonsmoking } \\
\text { controls }\end{array}$ & 20 & 35 & $62 \pm 11$ & & $\mathrm{FEV}_{1}: 101 \pm 16 \%$ pred & $25 \pm 3$ & $\begin{array}{l}0 \% \text { smokers; } 0 \\
\text { pack-years }\end{array}$ & & & - \\
\hline \multirow[t]{2}{*}{$\begin{array}{l}\text { Gelinas et al. } \\
\text { [39] }\end{array}$} & COPD patients & 24 & 54 & $\begin{array}{l}70 \\
(64- \\
75)\end{array}$ & $\begin{array}{l}\text { FEV } \\
\mathrm{FEV}_{1} / \mathrm{FVC}<0.7 \text { and }<\text { lower limit of } \\
\text { normal }\end{array}$ & $\mathrm{FEV}_{1}: 68 \pm 19 \%$ pred & $28 \pm 3$ & $\mid \begin{array}{lr}0 \% & \text { smokers; } \\
35 \pm 19 & \text { pack- } \\
\text { years } & \end{array}$ & - & - & - \\
\hline & Healthy controls & 20 & 50 & $\begin{array}{l}62 \\
(62- \\
66)\end{array}$ & & $\mathrm{FEV}_{1}: 113 \pm 16 \%$ pred & $26 \pm 3$ & $\begin{array}{l}0 \% \quad \text { smokers; } \\
6 \pm 10 \text { pack-years }\end{array}$ & - & - & - \\
\hline \multirow[t]{2}{*}{$\begin{array}{l}\text { Hartmann et } \\
\text { al.[29] }\end{array}$} & COPD patients & 10 & 40 & $67 \pm 3$ & $\begin{array}{l}\text { airflow obstruction (FEV1/FVC }< \\
0.70 \text { ) evident on spirometry }\end{array}$ & $\mathrm{FEV}_{1}: 60 \pm 5 \%$ pred & $25 \pm 2$ & $\begin{array}{l}0 \% \text { smokers } \\
45 \pm 5 \text { pack-years }\end{array}$ & 50 & - & - \\
\hline & Healthy controls & 10 & 40 & $66 \pm 2$ & & $\mathrm{FEV}_{1}: 107 \pm 4 \%$ pred & $25 \pm 1$ & $\begin{array}{l}0 \% \text { smokers } \\
5 \pm 4 \text { pack-years }\end{array}$ & 10 & - & - \\
\hline \multirow[t]{2}{*}{ Ives et al.[30] } & COPD patients & 30 & 50 & $66 \pm 2$ & $\begin{array}{l}\text { post-bronchodilator FEV1/FVC } \\
\text { ratio }<0.7\end{array}$ & $\mathrm{FEV}_{1}: 55 \pm 4$ \%pred & $26 \pm 1$ & $0 \%$ smokers & 57 & - & 7 \\
\hline & Controls & 30 & 50 & $66 \pm 2$ & & $\mathrm{FEV}_{1}: 107 \pm 4 \%$ pred & $25 \pm 1$ & $0 \%$ smokers & 23 & 3 & 3 \\
\hline \multirow[t]{2}{*}{$\begin{array}{l}\text { Kuzubova et } \\
\text { al.[37] }\end{array}$} & COPD patients & 63 & 100 & $60 \pm 1$ & FEV1/FVC spirometry & $\mathrm{FEV}_{1}: 45 \pm 2 \%$ pred & & $\begin{array}{l}100 \% \text { current or } \\
\text { ex-smokers; } \\
33 \pm 2 \text { pack-years }\end{array}$ & & & \\
\hline & Controls & 95 & 100 & $57 \pm 2$ & & & & $\begin{array}{l}57 \% \text { current or } \\
\text { ex-smokers }\end{array}$ & & & \\
\hline $\begin{array}{l}\text { Marchetti et } \\
\text { al.[31] }\end{array}$ & COPD patients & 8 & 50 & $61 \pm 8$ & $\begin{array}{l}\text { COPD defined using recent } \\
\text { guidelines }\end{array}$ & $\mathrm{FEV}_{1}: 33 \pm 22 \%$ pred & $29 \pm 7$ & $\begin{array}{lr}13 \% & \text { smokers; } \\
51 \pm 22 & \text { pack- } \\
\text { years } & \end{array}$ & 50 & 13 & - \\
\hline
\end{tabular}




\begin{tabular}{|c|c|c|c|c|c|c|c|c|c|c|c|}
\hline & Controls & 9 & 67 & $53 \pm 6$ & & & & $\begin{array}{l}0 \% \text { smokers; } 0 \\
\text { pack-years }\end{array}$ & 11 & - & - \\
\hline \multirow[t]{2}{*}{$\begin{array}{l}\text { Moro } \\
\text { al.[32] }\end{array}$} & COPD patients & 44 & 61 & 77 & $\begin{array}{l}\text { COPD according to American } \\
\text { Thoracic Society standards }\end{array}$ & FEV $_{1}: 1.43 \mathrm{~L}$ & $29 \pm 7$ & \begin{tabular}{|lr}
$30 \%$ & smokers; \\
$25 \pm 30$ & pack- \\
years & \\
\end{tabular} & 73 & 23 & 16 \\
\hline & Controls & 48 & 27 & 73 & - & $\mathrm{FEV}_{1}: 1.91 \mathrm{~L}$ & $27 \pm 6$ & \begin{tabular}{|lr}
$15 \%$ & smokers; \\
$15 \pm 26$ & pack- \\
years & \\
\end{tabular} & 81 & 15 & 23 \\
\hline \multirow[t]{2}{*}{$\begin{array}{l}\text { Özben } \\
\text { al.[33] }\end{array}$} & $\begin{array}{l}\text { COPD patients } \\
\text { after exacerbation }\end{array}$ & 30 & 73 & $64 \pm 11$ & $\begin{array}{l}\text { COPD according to the } \\
\text { guidelines of the American } \\
\text { Thoracic Society / European } \\
\text { Respiratory Society }\end{array}$ & $\mathrm{FEV}_{1}: 51 \pm 15 \%$ pred & $29 \pm 4$ & \begin{tabular}{ll|}
$100 \%$ & ex- \\
smokers
\end{tabular} & 87 & 43 & 33 \\
\hline & Controls & 20 & 75 & $62 \pm 7$ & - & - & $29 \pm 4$ & $\begin{array}{l}100 \% \quad \text { ex- } \\
\text { smokers }\end{array}$ & 90 & 45 & 40 \\
\hline \multirow[t]{3}{*}{$\begin{array}{l}\text { Pizarro et } \\
\text { al.[38] }\end{array}$} & COPD patients & 62 & 94 & $62 \pm 8$ & $\begin{array}{l}\text { COPD according to GOLD } \\
\text { guidelines }\end{array}$ & $\mathrm{FEV}_{1}: 83 \pm 18 \%$ pred & $26 \pm 3$ & $\begin{array}{lr}47 \% & \text { smokers; } \\
60 \pm 32 & \text { pack- } \\
\text { years } & \\
\end{array}$ & - & - & - \\
\hline & Controls & 18 & 39 & $58 \pm 6$ & - & $\mathrm{FEV}_{1}: 106 \pm 7 \%$ pred & $25 \pm 3$ & $\begin{array}{l}\text { non-smokers; } 0 \\
\text { pack-years }\end{array}$ & - & - & - \\
\hline & Controls & 17 & 71 & $59 \pm 8$ & - & FEV $_{1}: 100 \pm 12 \%$ pred & $25 \pm 3$ & \begin{tabular}{|lr}
$100 \%$ & smokers; \\
$41 \pm 21$ & pack- \\
years & \\
\end{tabular} & - & - & - \\
\hline $\begin{array}{l}\text { Urban et } \\
\text { al.[34] }\end{array}$ & COPD patients & 18 & 67 & $\begin{array}{l}67 \\
165-\end{array}$ & $\begin{array}{l}\text { evidence of airflow obstruction } \\
\text { on spirometry (FEV1/FVC ratio }\end{array}$ & $\mathrm{FEV}_{1}: 39(28-55)$ & $27(24-28)$ & $0 \%$ smokers & - & - & - \\
\hline
\end{tabular}




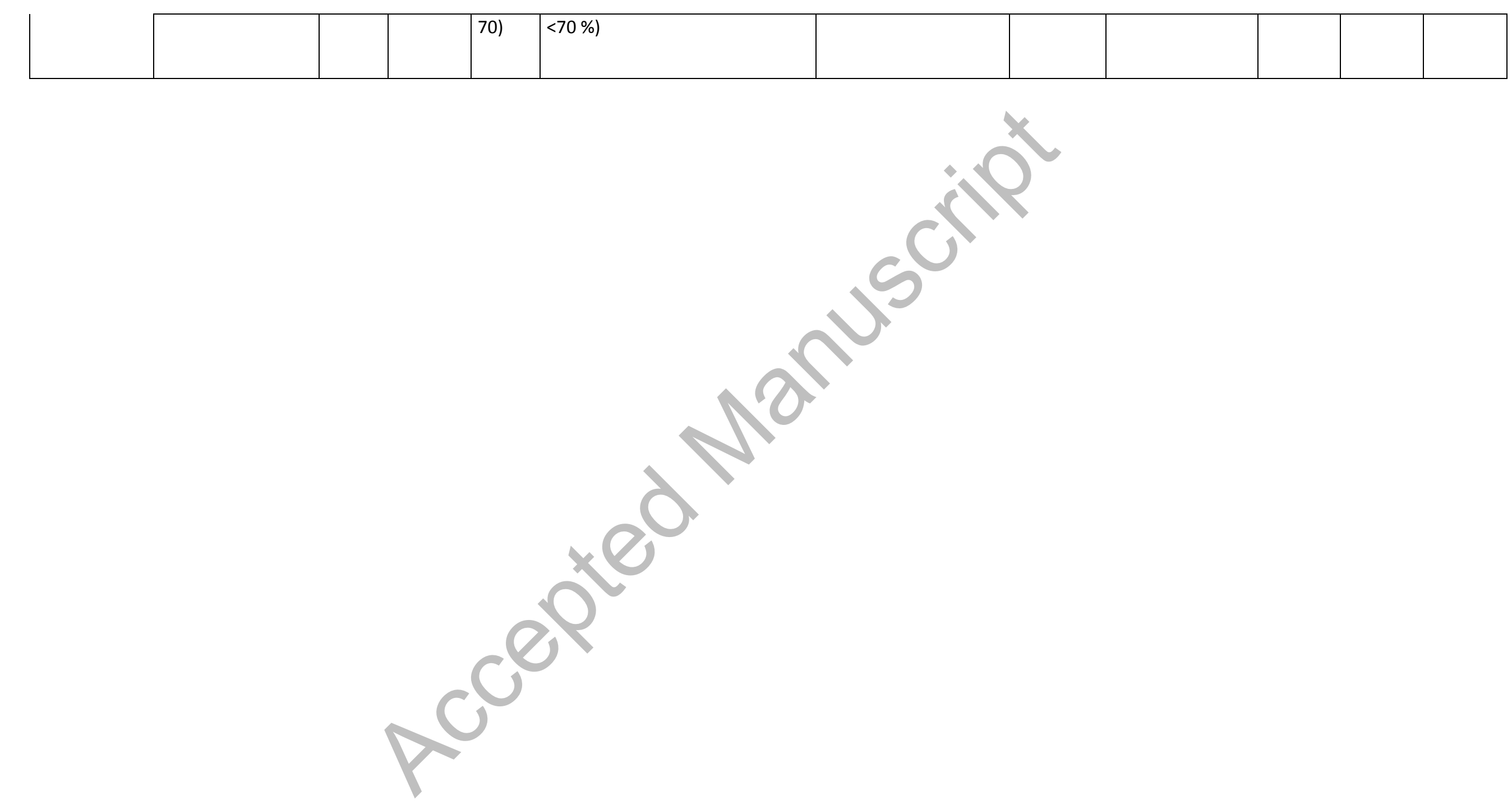


Table 2: Main study results

\begin{tabular}{|c|c|c|c|}
\hline Authors & Year & $\begin{array}{l}\text { Non-invasive } \\
\text { assessment } \\
\text { method }\end{array}$ & Outcomes \\
\hline $\begin{array}{l}\text { Barr et } \\
\text { al.[22] }\end{array}$ & 2007 & FMD & $\begin{array}{l}\text { - } 1 \text { standard deviation decrease in FMD was associated with a } 132-\mathrm{ml}(95 \% \mathrm{Cl}: 16-248 \mathrm{ml} ; \mathrm{P}=0.03) \text { decrement in } \\
\left.\mathrm{FEV}_{1} \text { and a } 2.6 \% \text { ( } 95 \% \mathrm{Cl}: 0.5-4.7 \% ; \mathrm{P}<0.02\right) \text { increase in } \mathrm{CT} \text { percentage of emphysema in fully adjusted models. } \\
\text { - Impaired endothelial function was associated with lower } \mathrm{FEV} 1 \text { and higher } \mathrm{CT} \text { percentage of emphysema in } \\
\text { former smokers early in COPD. }\end{array}$ \\
\hline $\begin{array}{l}\text { Blum et al. } \\
\text { [23] }\end{array}$ & 2014 & FMD & $\begin{array}{l}\text { - Baseline diameter of the brachial artery was larger in COPD patients compared with controls }(0.41 \pm 0.06 \mathrm{~cm} \text { vs. } \\
0.35 \pm 0.06 \mathrm{~cm} ; \mathrm{p}=0.003) \text {. } \\
\text { - The absolute change in diameter post hyperemia was significantly less in patients }(0.004 \pm 0.02 \mathrm{~cm} \text { vs. } 0.05 \pm 0.02 \\
\mathrm{cm} ; \mathrm{p}<0.001) \text {. } \\
\text { - } \text { COPD patients responded to the hyperemic trigger by constriction instead of dilatation (FMD\%: }-0.6 \pm 6.3 \% \text { in } \\
\text { patients vs. } 15.6 \pm 7.6 \% \text { in controls; } p<0.001) \text {. } \\
\text { - Patients with COPD had severe endothelial dysfunction manifested as impairment in the ability to dilate the } \\
\text { brachial artery. }\end{array}$ \\
\hline
\end{tabular}




\begin{tabular}{|c|c|c|c|}
\hline $\begin{array}{l}\text { Boyer } \\
\text { al.[24] }\end{array}$ & 2011 & FMD & $\begin{array}{l}\text { - Polycythemic patients had larger brachial artery diameter than normocythemic patients }(5.2 \pm 0.2 \mathrm{~cm} \text { vs. } \\
4.5 \pm 0.2 \mathrm{~cm} ; \mathrm{p}<0.02) \text {. } \\
\text { - } \text { FMD was increased in the polycythemic patients compared to normocythemic patients }(0.25 \pm 0.02 \text { vs. } \\
0.15 \pm 0.02 \mathrm{~mm} ; \mathrm{p}=0.01 \text { or } 3.97 \pm 0.39 \text { vs. } 2.85 \pm 0.25 \% ; p<0.02) \text {. } \\
\text { - } \quad \text { Acetylcholine-induced vasodilation was markedly impaired in the polycythemic patients }(p=0.03) \text {. } \\
\text { - Polycythemia induced by chronic or intermittent hypoxia may have no adverse effects on vascular function. }\end{array}$ \\
\hline $\begin{array}{l}\text { Clarenbach } \\
\text { et al.[25] }\end{array}$ & 2013 & FMD & $\begin{array}{l}\text { FMD was associated with FEV1 } \% \text { predicted }(\beta=0.04 ; p<0.01) \text {. } \\
\text { FMD in patients with GOLD stage I/II was } 4.3 \pm 2.0 \% \text { pred and was progressively impaired in patients with stage } \\
\text { III ( } 2.8 \pm 1.5 \% \text { pred) and stage IV ( } 2.0 \pm 1.3 \% \text { pred). } \\
\text { FEV1 and physical activity were independently associated with FMD. } \\
\text { Results in inactive patients (below the median number of steps per day) showed a stronger association } \\
\text { between FEV1 and FMD compared to the active patients (above the median number of steps per day)( } \beta=0.06 \text {; } \\
\text { p<0.01 vs. } \beta=0.03 ; p=0.11) \text {. } \\
\text { Severity of airflow obstruction is a significant determinant of endothelial function in patients with COPD. A } \\
\text { high level of physical activity seems to have a favorable effect on this association. }\end{array}$ \\
\hline $\begin{array}{l}\text { Clarenbach } \\
\text { et al.[36] }\end{array}$ & 2015 & FMD & $\begin{array}{l}\text { - } \quad \text { FMD increased in the intervention group compared with the control group ( }+2.4 \pm 1.1 \% \text { vs. }-0.5 \pm 0.6 \% ; P<0.001) \text {. } \\
\text { - } \quad \text { Endothelial function improved } 3 \text { months after lung volume reduction surgery in patients with severe COPD and }\end{array}$ \\
\hline
\end{tabular}




\begin{tabular}{|c|c|c|c|c|}
\hline & & & & emphysema. Lung volume reduction may therefore have beneficial effects on cardiovascular outcomes. \\
\hline $\begin{array}{l}\text { Costanzo et } \\
\text { al.[26] }\end{array}$ & 2016 & FMD & - & $\begin{array}{l}\text { No difference in FMD between COPD and controls ( } 14.2 \pm 8 \% \text { vs. } 12.3 \pm 6.8 \% ; p=0.10) \text {. } \\
\text { No difference in arterial stiffness between COPD and controls ( } 30.0 \pm 6.4 \% \text { vs. } 28.2 \pm 9.8 \% ; p=0.30) \\
\text { No difference in mean concentrations of inflammation markers (IL-6 and CRP; } p>0.05) \text {. } \\
\text { Among COPD patients there was an inverse correlation between arterial stiffness and FEV1 ( } r=-0.349 \text {; } \\
p=0.02) \text {, which is explained neither by endothelial function nor bystemic inflammation. }\end{array}$ \\
\hline $\begin{array}{l}\text { de Matthaeis } \\
\text { et al.[27] }\end{array}$ & 2014 & FMD & - & $\begin{array}{l}\text { No significant difference in mean FMD between COPD at baseline and controls }(10.0 \% \pm 2.8 \% \text { vs. } 9.6 \% \pm 2.7 \% \text {; } \\
p=0.344) \text {. } \\
\text { Significant differences in mean values of FMD before and after standard treatment for acute exacerbation of } \\
\text { COPD }(10.0 \% \pm 2.8 \% \text { vs. } 8.28 \% \pm 2.01 \% ; p<0.001) \text { and blood flow rate }(1.5 \pm 0.3 \mathrm{~m} / \mathrm{s} \text { vs. } 1.5 \pm 0.3 \mathrm{~m} / \mathrm{s} ; \mathrm{p}=0.001) \text {. } \\
\text { Significant correlations were found for FMD values and } \mathrm{pCO}_{2} \text { values at baseline }(\mathrm{r}=0.294 ; \mathrm{p}=0.004) \text { and for } \\
\text { relative changes in FMD and } \mathrm{pCO}_{2} \text { levels before and after standard treatment for acute exacerbation of COPD } \\
(\mathrm{r}=0.23 ; \mathrm{p}=0.023) \text {. } \\
\text { Patients with higher baseline FMD }(>10 \%) \text { showed greater modification with regard to } \mathrm{pCO}_{2} \text { changes }(2.6 \pm 1.39 \\
\text { vs. } 1.59 \pm 1.4, \mathrm{P}=0.012) \text {. }\end{array}$ \\
\hline & & & - & Hypercapnia during acute exacerbations of COPD can influence endothelium-dependent vasodilation, and a \\
\hline
\end{tabular}




\begin{tabular}{|c|c|c|c|c|}
\hline & & & - & $\begin{array}{l}\text { larger decrease in } \mathrm{FMD} \text { could point to greater reactivity to } \mathrm{PCO}_{2} \text {. } \\
\text { Vascular reactivity in acute COPD exacerbations in the elderly depends on integrity of the vascular } \\
\text { endothelium. }\end{array}$ \\
\hline $\begin{array}{l}\text { Eickhoff et } \\
\text { al. [28] }\end{array}$ & 2008 & $\begin{array}{l}\text { FMD and } \\
\text { NMD }\end{array}$ & 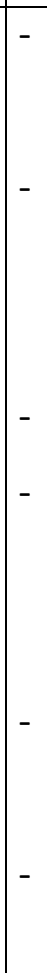 & $\begin{array}{l}\text { Baseline brachial artery diameter was significantly higher in patients with COPD compared to nonsmoking } \\
\text { controls ( } 3.64 \pm 0.63 \mathrm{~mm} \text { vs. } 3.28 \pm 0.61 \mathrm{~mm} ; \mathrm{p}>0.05) \text {. } \\
\text { Both FMD and NMD of the brachial artery were significantly lower in patients with stable COPD compared to } \\
\text { smoking and nonsmoking control subjects ( } 11 \pm 3 \% \text { and } 22 \pm 6 \% \text { vs. } 16 \pm 2 \% \text { and } 26 \pm 7 \% \text { and } 19 \pm 3 \% \text { and } 29 \pm 7 \% \text {, } \\
\text { respectively; } p<0.05) \text {. } \\
\text { Levels of inflammatory mediators were higher in patients than they were in control subjects ( }<<0.05) \text {. } \\
\text { Stepwise multiple regression analysis showed that age, sex, baseline brachial artery diameter, CRP level, } \\
\text { leukocyte count, blood glucose level, and FEV }{ }_{1} \% \text { pred were independent predictors of FMD in patients with } \\
\text { COPD. There was no relation between FMD and pack-years of smoking. } \\
\text { Baseline brachial artery diameter was the only independent predictor of NMD in patients with COPD. } \\
\text { Both endothelium-dependent and endothelium-independent vasodilation is significantly impaired in patients } \\
\text { with stable COPD. }\end{array}$ \\
\hline
\end{tabular}




\begin{tabular}{|c|c|c|c|c|}
\hline & & & - & $\begin{array}{l}\text { Impaired flow-mediated dilation was strongly related to systemic inflammation and airway obstruction, which } \\
\text { may help explain the increased cardiovascular morbidity in patients with COPD. }\end{array}$ \\
\hline $\begin{array}{l}\text { Gelinas et al. } \\
\text { [39] }\end{array}$ & 2017 & $\begin{array}{l}\text { FMD } \\
\text { NMD }\end{array}$ & - & $\begin{array}{l}\text { Exercise training had no significant effect on FMD independent dilation or any shear stress measures in } \\
\text { patients with COPD or healthy controls. } \\
\text { FMD corrected for baseline diameter was unchanged in COPD }(4.7 \pm 1.9 \% \text { vs. } 4.8 \pm 2.0 \%, p=0.78) \text { and controls } \\
(4.3 \pm 2.3 \% \text { vs. } 4.6 \pm 2.2 \%, p=0.66) \text {. } \\
\text { There were no significant differences at baseline, post-training, or between change scores for any FMD or } \\
\text { NMD variables when comparing COPD to controls. } \\
\text { An aerobic training program does not improve vascular structure and function in patients with COPD. }\end{array}$ \\
\hline $\begin{array}{l}\text { Hartmann et } \\
\text { al. [29] }\end{array}$ & 2016 & $\begin{array}{ll}\text { FMD } & \text { and } \\
\text { NMD } & \end{array}$ & - & $\begin{array}{l}\text { FMD } \% \text { and absolute change in brachial diameter were not different between COPD and controls after sham- } \\
\text { saline infusion ( } 6.0 \% \pm 0.9 \% \text { vs. } 5.9 \% \pm 1.0 \% \text {; } p>0.05) \text {. } \\
\text { Vitamin C infusion significantly increased FMD } \% \text { to a similar extent in both groups ( } 8.1 \% \pm 1.3 \% \text { vs. } 7.4 \% \pm 0.8 \% \text {; } \\
\text { P>0.05). However, baseline diameter was lower after vitamin C in both groups ( } 3.52 \pm 0.18 \mathrm{~mm} \text { vs. } 3.69 \pm 0.16 \\
\mathrm{~mm} \text { in COPD and } 3.62 \pm 0.20 \mathrm{~mm} \text { vs. } 3.78 \pm 0.23 \mathrm{~mm} \text { in controls; } p<0.05) \text {. } \\
\text { NMD initiated similar responses between groups ( } 25.6 \% \pm 1.6 \% \text { in COPD vs. } 23.5 \% \pm 2.3 \% \text { in controls; } p>0.05) \text {. } \\
\text { Similar changes were found between groups when comparing the absolute change in brachial artery diameter } \\
\text { with nitroglycerine administration }(+0.85 \pm 0.08 \mathrm{~mm} \text { in COPD and }+0.85 \pm 0.04 \mathrm{~mm} \text { in controls; } p>0.05) \text {. } \\
\text { FMD in the brachial artery was not different in COPD patients and controls. Vitamin } \mathrm{C} \text { had an overall }\end{array}$ \\
\hline
\end{tabular}




\begin{tabular}{|c|c|c|c|c|}
\hline & & & & improvement on this parameter. \\
\hline $\begin{array}{l}\text { Ives } \\
\text { al.[30] }\end{array}$ & 2014 & FMD & - & $\begin{array}{l}\text { COPD patients displayed lower basal FMD compared to controls ( } 3.1 \pm 0.5 \% \text { vs. } 6.7 \pm 0.6 \% \text {; } p<0.05 \text { ), which was } \\
\text { significantly improved with antioxidant cocktail in COPD ( } 3.1 \pm 0.5 \% \text { vs. } 4.7 \pm 0.6 \% ; p<0.05 \text {; placebo vs cocktail), } \\
\text { but not controls ( } 6.7 \pm 0.6 \% \text { vs. } 6.9 \pm 0.7 \% \text {; } p>0.05 \text {; placebo vs cocktail). } \\
\text { The antioxidant cocktail also improved pulse wave velocity (PWV, measure of vascular stiffness) in patients } \\
\text { with COPD ( } 14 \pm 1 \mathrm{~m} / \mathrm{s} \text { vs. } 11 \pm 1 \mathrm{~m} / \mathrm{s} ; \mathrm{p}<0.05 \text {; placebo vs. cocktail) while not affecting controls ( } 11 \pm 2 \mathrm{~m} / \mathrm{s} \text { vs. } \\
10 \pm 1 \mathrm{~m} / \mathrm{s} ; \mathrm{p}>0.05 \text {; placebo vs cocktail. } \\
\text { Patients with COPD displayed impaired vascular function, as assessed by FMD and PWV, compared with } \\
\text { controls, which can be acutely mitigated by an oral antioxidant. }\end{array}$ \\
\hline $\begin{array}{l}\text { Kuzubova et } \\
\text { al.[37] }\end{array}$ & 2013 & FMD & - & $\begin{array}{l}\text { Endothelial dysfunction (FMD<10\%) was present in } 48 \% \text { of COPD patients. } \\
\text { Detectable endothelial dysfunction in COPD patients was shown to correlate with high-producer D allele of } \\
\left.\text { ACE gene (odds ratio: } 6.632, \mathrm{Cl}: 1.67-26.31 ; \mathrm{chi}^{2}=8.39 ; \mathrm{p}=0.004\right) \text {. } \\
\text { A high-producer D allele of ACE-1 gene seems to be associated with endothelial dysfunction in COPD patients, } \\
\text { thus confirming a pathogenic significance of this gene polymorphism which is known to predispose for various } \\
\text { types of other common vascular disorders. }\end{array}$ \\
\hline $\begin{array}{l}\text { Marchetti et } \\
\text { al.[31] }\end{array}$ & 2011 & $\begin{array}{|ll|}\text { FMD } & \text { and } \\
\text { NMD } & \\
\end{array}$ & - & $\begin{array}{l}\text { In acute exacerbation of COPD FMD was markedly reduced compared to controls }(2.8 \pm 1.7 \% \text { vs. } 10.8 \pm 4,7 \% \text {; } \\
\text { p<0.001). } \\
\text { NMD was markedly impaired during AECOPD compared to controls }(8.0 \pm 4.3 \% \text { vs. } 21.4 \pm 6,0 \% ; p<0.001) \text {. }\end{array}$ \\
\hline
\end{tabular}




\begin{tabular}{|c|c|c|c|}
\hline & & & $\begin{array}{l}\text { - Significant improvements were found in FMD }(2.6 \pm 1.5 \% \text { vs. } 5.1 \pm 2.4 \% ; p=0.04) \text { and NMD }(5.0 \pm 2.6 \% \text { vs. } \\
13.3 \pm 4.5 ; p=0.02) \text { after resolution of acute exacerbation of COPD. } \\
\text { - Endothelial and vascular smooth muscle function is markedly impaired during AECOPD requiring } \\
\text { hospitalization and improves following resolution. }\end{array}$ \\
\hline $\begin{array}{l}\text { Moro et al. } \\
\text { [32] }\end{array}$ & 2008 & $\begin{array}{l}\text { FMD and } \\
\text { NMD }\end{array}$ & $\begin{array}{l}\text { - } \text { COPD patients had worse mean FMD and NMD compared to controls ( } 5.4 \% \text { vs. } 8.9 \% ; p<0.001 \text { and } 12.0 \% \text { vs. } \\
\text { 13.9\%; } p=0.007 \text {, respectively). } \\
\left.\text { - } \text { FMD was inversely related to } \mathrm{FEV}_{1} / \mathrm{VC} \text { ratio ( } r=-0.327 ; p=0.030\right) \text {. } \\
\text { The negative association between } \mathrm{COPD} \text { and } \mathrm{FMD} \text { and between } \mathrm{COPD} \text { and NMD was confirmed after } \\
\mathrm{p}<0.001 \text {, respectively). } \\
\text { - Endothelial-dependent and, to a lesser extent, endothelial-independent dilations are significantly impaired in } \\
\text { COPD, and the impairment is proportional to the severity of bronchial obstruction. }\end{array}$ \\
\hline $\begin{array}{l}\text { Özben } \\
\text { al.[33] }\end{array}$ & 2010 & FMD & $\begin{array}{l}\text { Parameters of FMD during acute exacerbation were significantly lower than those obtained after recovery } \\
\text { (absolute change: } 0.23 \pm 0.12 \mathrm{~mm} \text { vs. } 0.38 \pm 0.17 \mathrm{~mm} ; \mathrm{p}<0.001 \text {; percentage change: } 6.44 \pm 3.99 \% \text { vs. } 10.42 \pm 4.86 \% \text {; } \\
p<0.001 \text { ) and compared to those of the control group (absolute change: } 0.36 \pm 0.13 \mathrm{~mm} ; \mathrm{p}=0.001 \text {; percentage } \\
\text { change: } 9.77 \pm 3.83 \% ; p=0.003 \text { ). } \\
\text { FMD increased significantly after recovery, yielding similar values to those of the controls. Improvements in } \\
\text { FMD were significant in both sexes. }\end{array}$ \\
\hline
\end{tabular}




\begin{tabular}{|c|c|c|c|}
\hline & & & $\begin{array}{l}\text { - Acute COPD exacerbation is associated with worsening endothelial function, increasing the risk for } \\
\text { cardiovascular morbidity. }\end{array}$ \\
\hline $\begin{array}{ll}\text { Pizarro et } \\
\text { al.[38] }\end{array}$ & 2014 & FMD & $\begin{array}{l}\text { FMD was worse in both COPD patients and control smokers compared to control nonsmokers (0.9 (-1.3 to } \\
\text { 2.3)\% and } 0.0 \text { (-0.8 to } 1.6) \% \text { vs. } 2.4 \text { ( } 1.1 \text { to } 4.1) \% \text {, respectively). } \\
\text { - Interleukin-6, fibrinogen, high sensitivity C-reactive protein, vascular endothelial growth factor and tumor } \\
\text { necrosis factor were increased in COPD. } \\
\text { - In COPD patients, the number of circulating progenitor cells was inversely related to the flow-mediated } \\
\text { dilation of systemic arteries. } \\
\text { - Systemic vascular impairment in COPD is associated with smoking status but not with the reduced number of } \\
\text { circulating hematopoietic progenitors. The latter appears to be a consequence of the disease itself not related } \\
\text { to smoking status. }\end{array}$ \\
\hline $\begin{array}{l}\text { Urban } \\
\text { al.[34] }\end{array}$ & 2014 & $\begin{array}{ll}\text { FMD } & \text { and } \\
\text { NMD }\end{array}$ & 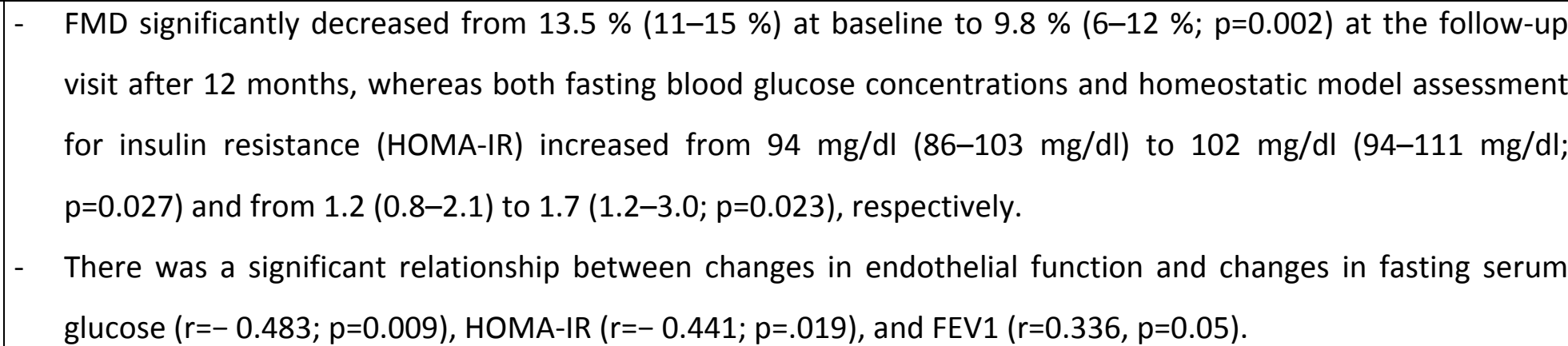 \\
\hline
\end{tabular}




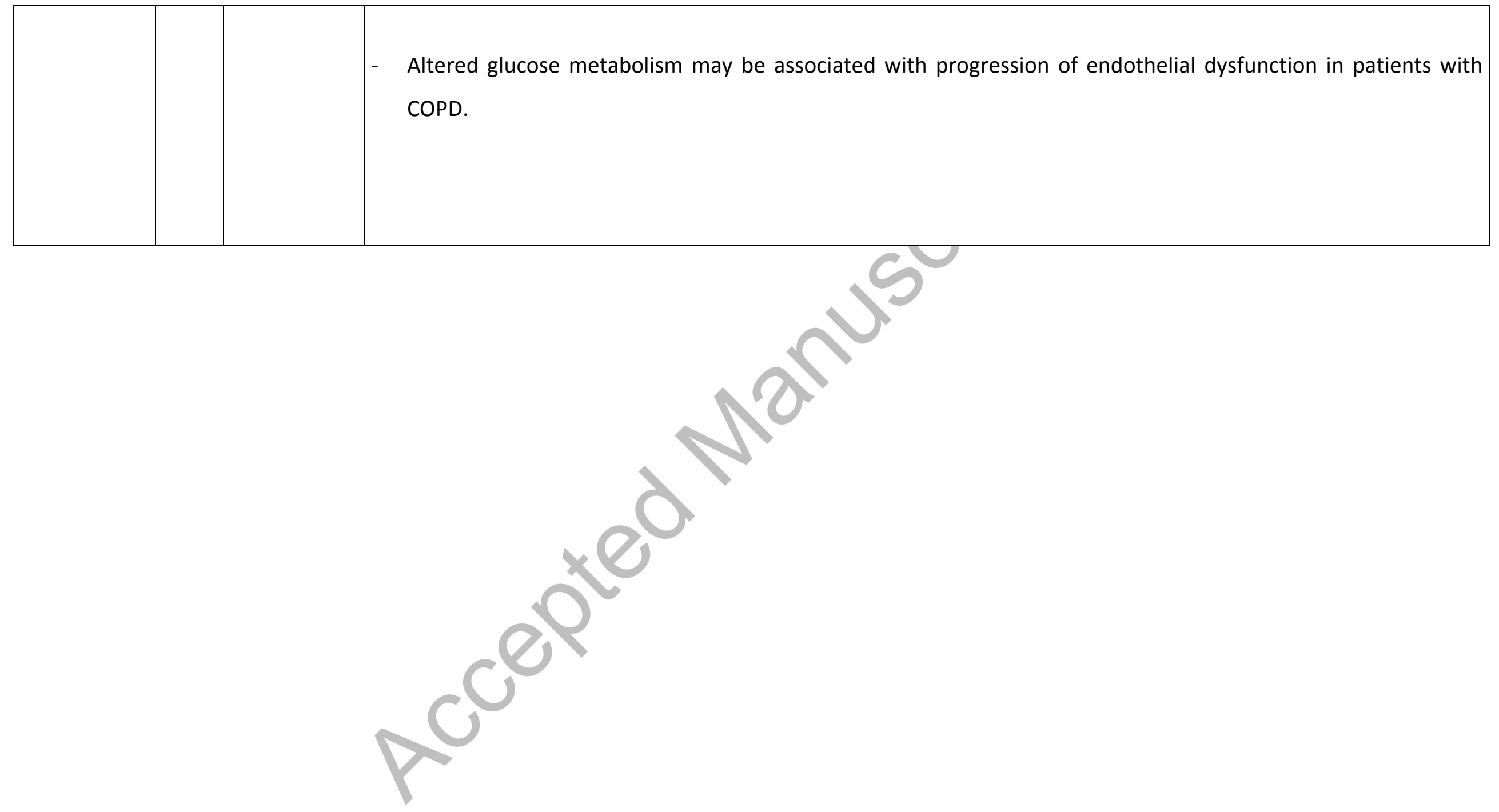




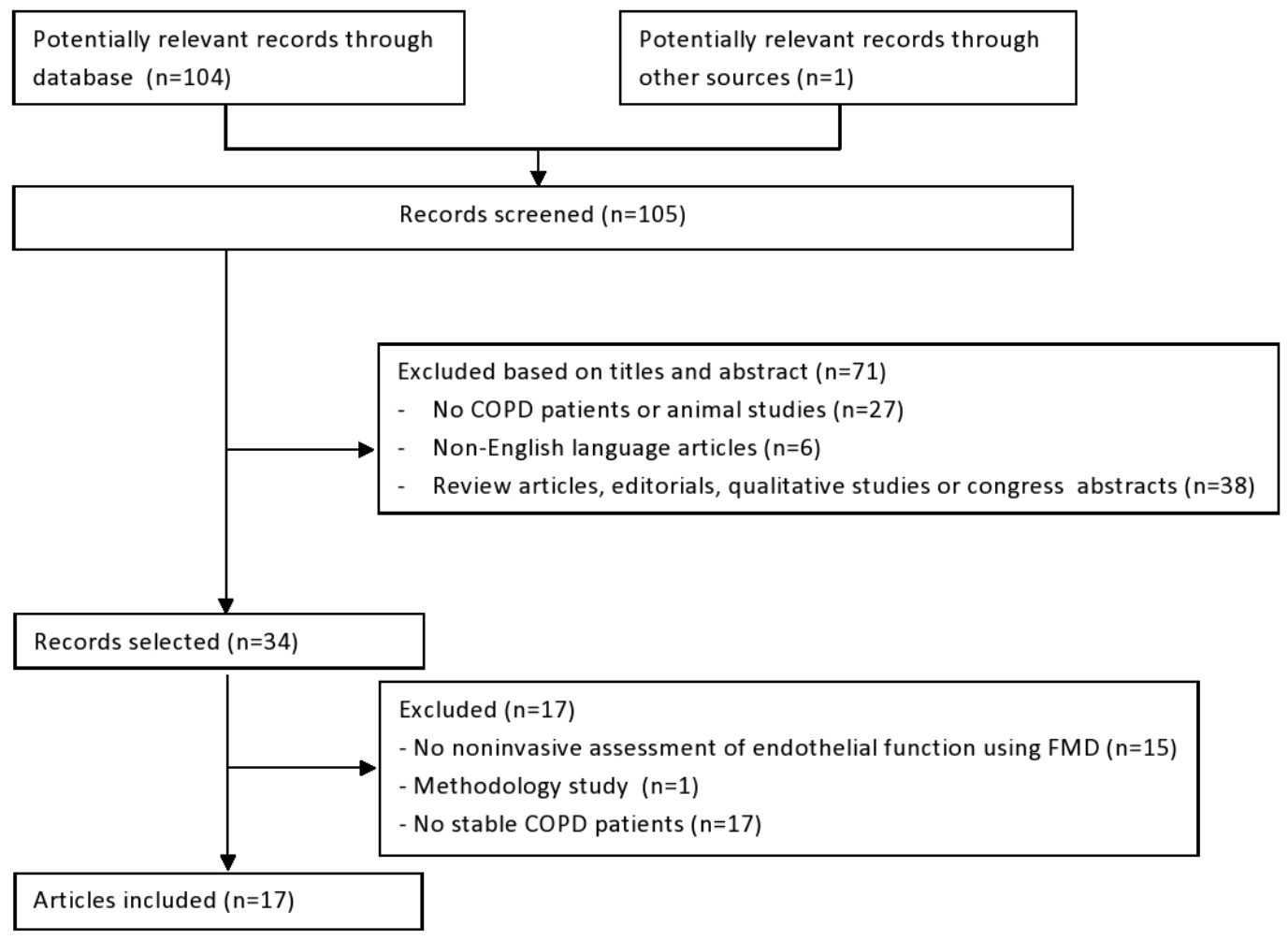

Figure 1: Study flow diagram 
Figure 2: Flow-mediated dilation of the brachial artery using ultrasound in patients with COPD versus control subjects.

\begin{tabular}{|c|c|c|c|c|c|c|c|c|c|c|}
\hline Blum et al. 2014 & -0.6 & 6.3 & 23 & 15.6 & 7.6 & 22 & $6.1 \%$ & $-16.20[-20.29,-12.11]$ & & $\begin{array}{c}\text { Mean Difference } \\
\text { IV, Random, } 95 \% \mathrm{Cl}\end{array}$ \\
\hline Castanzo et al. 2016 & 14.2 & 8 & 41 & 12.3 & 6.8 & 35 & $7.1 \%$ & $1.90[-1.43,5.23]$ & & \\
\hline de Matthaeis et al. 2014 & 8.3 & 2 & 96 & 9.6 & 2.7 & 76 & $10.5 \%$ & $-1.30[-2.03,-0.57]$ & - & \\
\hline Eickhaff et al. 2008 & 11 & 3 & 60 & 19 & 3 & 20 & $9.7 \%$ & $-8.00[-9.52,-6.48]$ & & \\
\hline Eickhoff et al. 2008 & 11 & 3 & 60 & 16 & 2 & 20 & $10.1 \%$ & $-5.00[-6.16,-3.84]$ & $=$ & \\
\hline Gelinas et al. 2017 & 4.7 & 1.9 & 24 & 4.3 & 2.3 & 20 & $10.0 \%$ & $0.40[-0.86,1.66]$ & & - \\
\hline Hartmann et al. 2016 & 6 & 0.9 & 10 & 5.9 & 1 & 10 & $10.4 \%$ & $0.10[-0.73,0.93]$ & & \\
\hline Ives et al. 2014 & 3.1 & 0.5 & 30 & 6.7 & 0.6 & 30 & $10.7 \%$ & $-3.60[-3.88,-3.32]$ & - & \\
\hline Marchetti et al. 2011 & 5.1 & 2.4 & 8 & 10.8 & 4.7 & 9 & $6.9 \%$ & $-5.70[-9.19,-2.21]$ & & \\
\hline Moro et al. 2008 & 5.4 & 3.1 & 44 & 8.2 & 2.1 & 48 & $10.2 \%$ & $-2.80[-3.89,-1.71]$ & $=$ & \\
\hline Ozben et al. 2010 & 10.42 & 4.86 & 30 & 9.77 & 3.83 & 20 & $8.5 \%$ & $0.65[-1.77,3.07]$ & & \\
\hline Total $(95 \% \mathrm{Cl})$ & & & 426 & & & 310 & $100.0 \%$ & $-3.22[-4.74,-1.69]$ & & \\
\hline $\begin{array}{l}\text { Heterageneity: Tau }{ }^{z}=5 \\
\text { Test for overall effect: } z\end{array}$ & $\begin{array}{l}C h i^{\mathbf{z}}= \\
4(P\end{array}$ & & & $0\langle P=$ & 1000 & & & & Stable COPD ${ }^{0}$ & ${ }^{0}{ }_{\text {Control }}^{10}$ \\
\hline
\end{tabular}

Figure 2: Flow-mediated dilation of the brachial artery using ultrasound in patients with COPD versus control subjects 
Figure 3: Nitroglycerine-mediated dilation of the brachial artery using ultrasound in patients with COPD versus control subjects

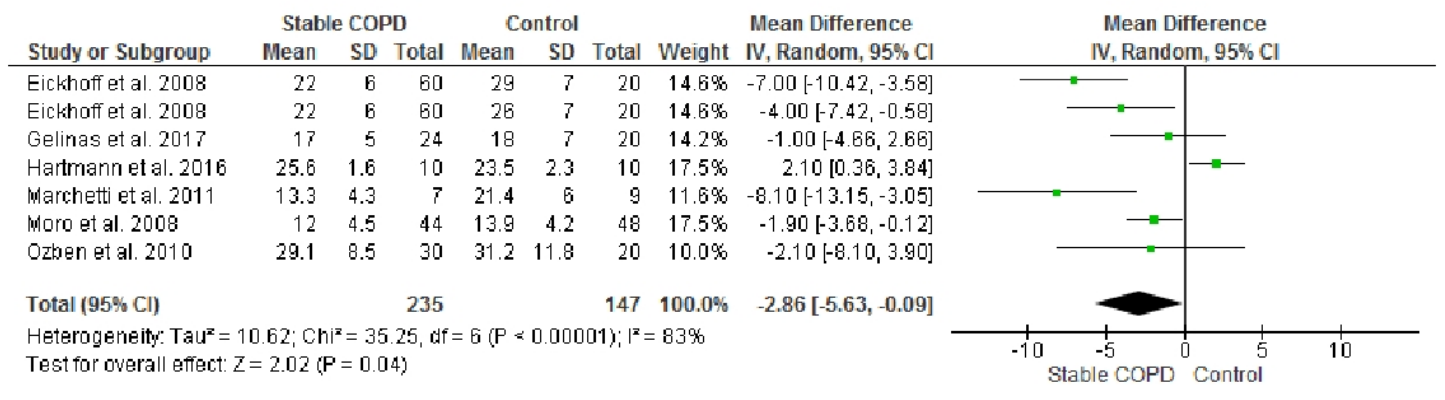

Figure 3: Nitroglycerine-mediated dilation of the brachial artery using ultrasound in patients with COPD versus control subjects 
Endothelial function in patents with COPD: a systematic review of studies using flow mediated dilatation 


\section{Methods}

\section{Search terms used for this review}

1. ("chronic obstruct* pulmon*" OR "COPD" OR "emphysema*" OR "chronic obstruct* bronchitis*" OR "chronic obstruct* airway*" OR "chronic obstruct* lung*" OR "obstruct* spirometr*") AND (endoth* OR "endoth* function" OR "endoth* dysfunction") AND ("non invasive" OR noninvasive OR non-invasive) AND (test* OR assessment* OR measurement* OR procedure*)

2. ("chronic obstruct* pulmon*" OR "COPD" OR "emphysema*" OR "chronic obstruct* bronchitis*" OR "chronic obstruct* airway*" OR "chronic obstruct* lung*" OR "obstruct* spirometr*") AND (endoth* OR "endoth* function" OR "endoth* dysfunction") AND ("flow mediated dilation" OR "flow-mediated dilation" OR "flow-mediated" OR "flowmediated" OR "FMD")

3. ("chronic obstruct* pulmon*" OR "COPD" OR "emphysema*" OR "chronic obstruct* bronchitis*" OR "chronic obstruct* airway*" OR "chronic obstruct* lung*" OR "obstruct* spirometr*") AND ("vascular function" OR "vascular dysfunction" OR "vascular respons*") AND ("non invasive" OR noninvasive OR non-invasive) AND (test* OR assessment* OR measurement* OR procedure*)

4. ("chronic obstruct* pulmon*" OR "COPD" OR "emphysema*" OR "chronic obstruct* bronchitis*" OR "chronic obstruct* airway*" OR "chronic obstruct* lung*" OR "obstruct* spirometr*") AND ("vascular function" OR "vascular dysfunction" OR "vascular respons*") AND ("flow mediated dilation" OR "flow-mediated dilation" OR "flow-mediated" OR "FMD") 
Supplemental Table 1. Methodological quality of the studies

\begin{tabular}{|c|c|c|c|c|c|c|c|c|c|}
\hline Study & 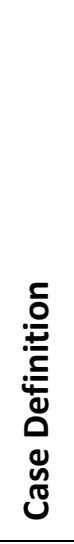 & 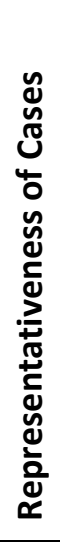 & 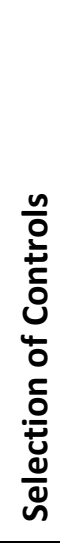 & 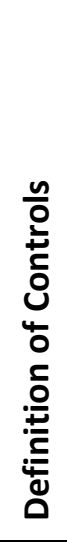 & 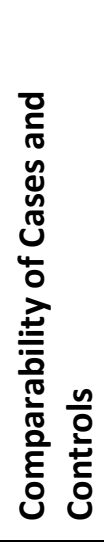 & 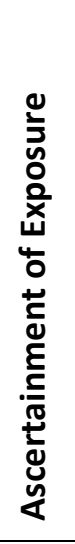 & 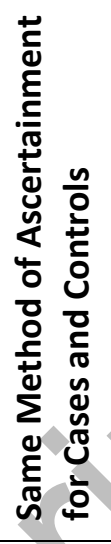 & 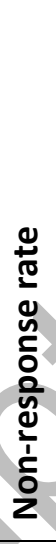 & Quality \\
\hline Blum et al. 2014 & $*$ & $*$ & $*$ & - & - & $*$ & $*$ & $*$ & 6 \\
\hline Costanzo et al. 2016 & $*$ & - & - & - & $* *$ & $*$ & $*$ & $*$ & 6 \\
\hline de Matthaeis et al. 2014 & * & $*$ & - & - & - & * & * & * & 5 \\
\hline Eickhoff et al. 2014 & * & $*$ & * & * & $* *$ & $*$ & * & * & 9 \\
\hline Gelinas et al. 2017 & * & * & $*$ & $*$ & $*$ & * & $*$ & $*$ & 8 \\
\hline Hartmann et al. 2016 & $*$ & - & $*$ & $*$ & $* *$ & $*$ & $*$ & $*$ & 8 \\
\hline Ives et al. 2014 & * & $*$ & $*$ & $*$ & $* *$ & $*$ & * & $*$ & 9 \\
\hline Marchetti et al 2011 & $*$ & $*$ & * & * & - & $*$ & $*$ & $*$ & 7 \\
\hline Moro et al. 2008 & $*$ & $*$ & $*$ & $*$ & $*$ & $*$ & $*$ & $*$ & 8 \\
\hline Özben et al. 2010 & $*$ & $*$ & - & $*$ & ** & $*$ & $*$ & $*$ & 8 \\
\hline
\end{tabular}


Figure E1 Funnel plot comparing studies using ultrasound-based flow-mediated dilation of the brachial artery

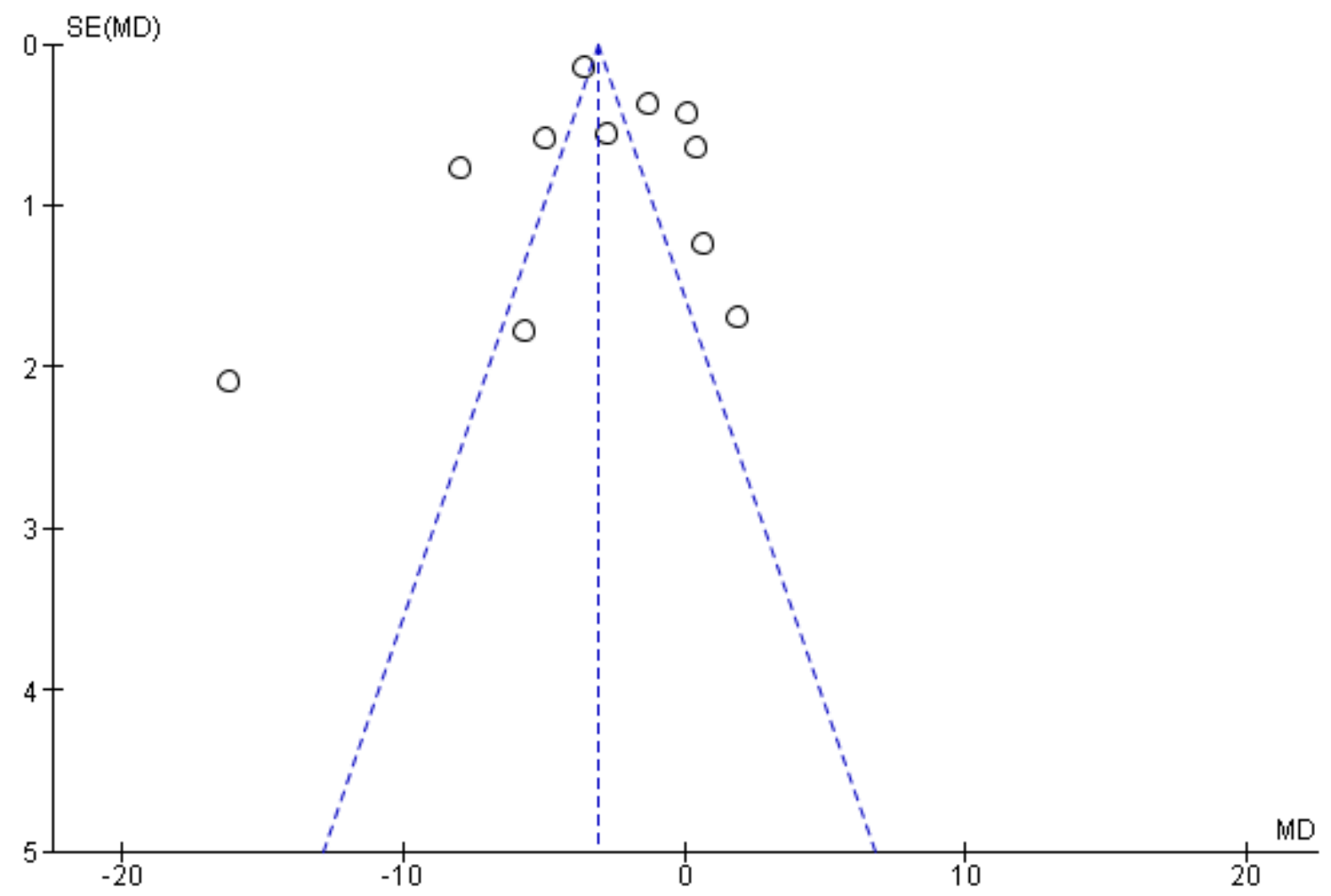

\begin{tabular}{|l|l|}
\hline \multicolumn{2}{|l|}{ Egger's regression intercept } \\
\hline Intercept & 0.53756 \\
\hline Standard error & 2.20881 \\
\hline $95 \%$ lower limit & -4.45910 \\
\hline $95 \%$ upper limit & 5.53423 \\
\hline t-value & 0.24337 \\
\hline p-value & 0.81317 \\
\hline Begg and Mazumdar rank correlation \\
\hline Kendall's S statistic (P-Q) & -9.00000 \\
\hline Kendall's tau without continuity correction \\
\hline Tau \\
\hline z-value for tau & -0.16364 \\
\hline p-value & 0.70065 \\
\hline Kendall's tau with continuity correction & 0.48352 \\
\hline Tau & -0.14545 \\
\hline z-value for tau & 0.62280 \\
\hline p-value & 0.53342 \\
\hline
\end{tabular}


Figure E2 Funnel plot comparing studies using ultrasound-based nitroglycerine-mediated dilation of the brachial artery of the brachial artery

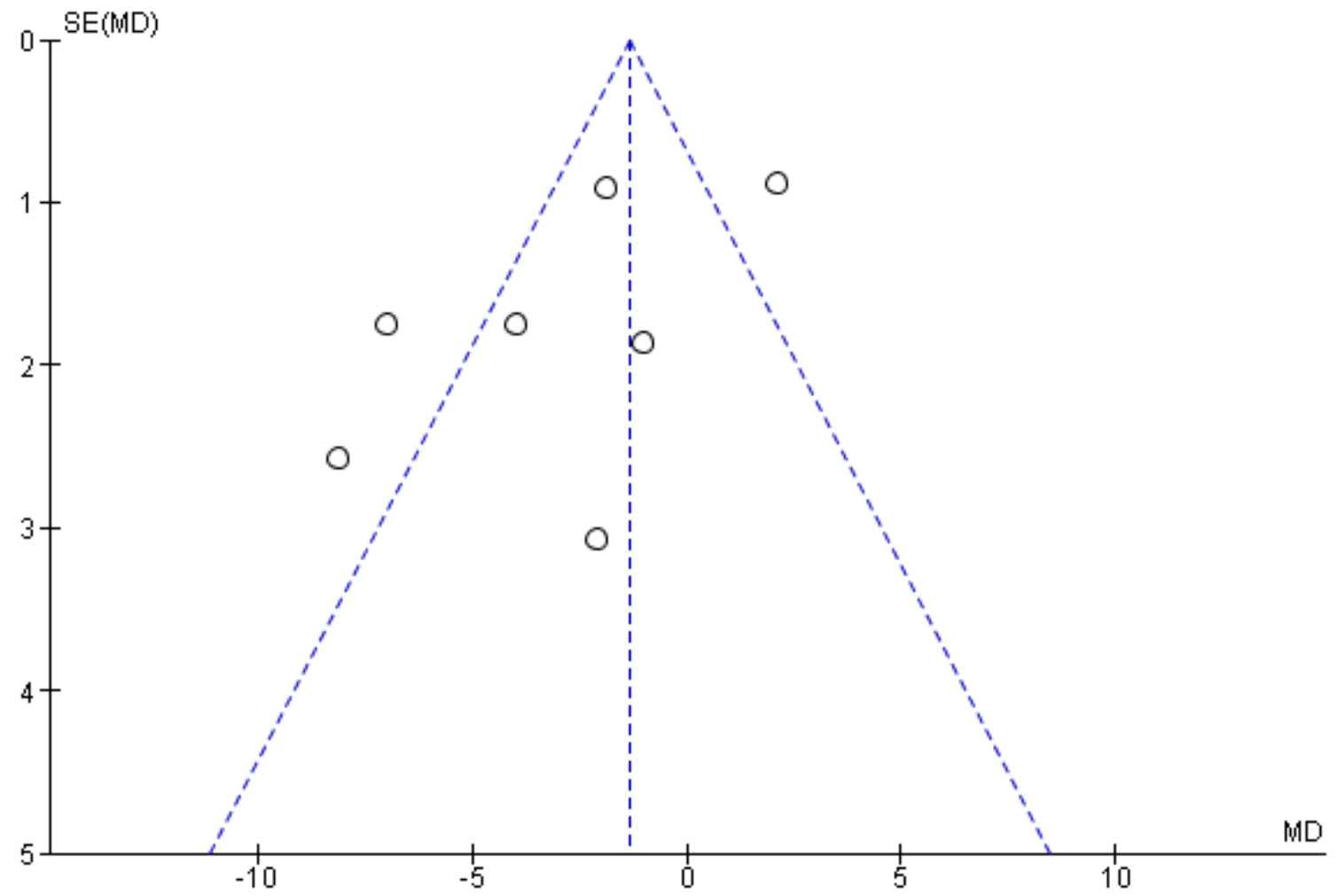

\begin{tabular}{|c|c|}
\hline \multicolumn{2}{|c|}{ Egger's regression intercept } \\
\hline Intercept & -3.55695 \\
\hline Standard error & 2.01738 \\
\hline 95\% lower limit & -8.74278 \\
\hline 95\% upper limit & 1.62888 \\
\hline t-value & 1.76316 \\
\hline p-value & 0.13816 \\
\hline \multicolumn{2}{|c|}{ Begg and Mazumdar rank correlation } \\
\hline Kendall's S statistic (P-Q) & -4.00000 \\
\hline \multicolumn{2}{|c|}{ Kendall's tau without continuity correction } \\
\hline Tau & -0.19048 \\
\hline z-value for tau & 0.60075 \\
\hline p-value & 0.54801 \\
\hline \multicolumn{2}{|c|}{ Kendall's tau with continuity correction } \\
\hline Tau & -0.14286 \\
\hline z-value for tau & 0.45056 \\
\hline p-value & 0.65230 \\
\hline
\end{tabular}


Figure 3E Subgroup analysis comparing endothelial function of COPD patients with smoking (a) and non-smoking controls (b)

a.

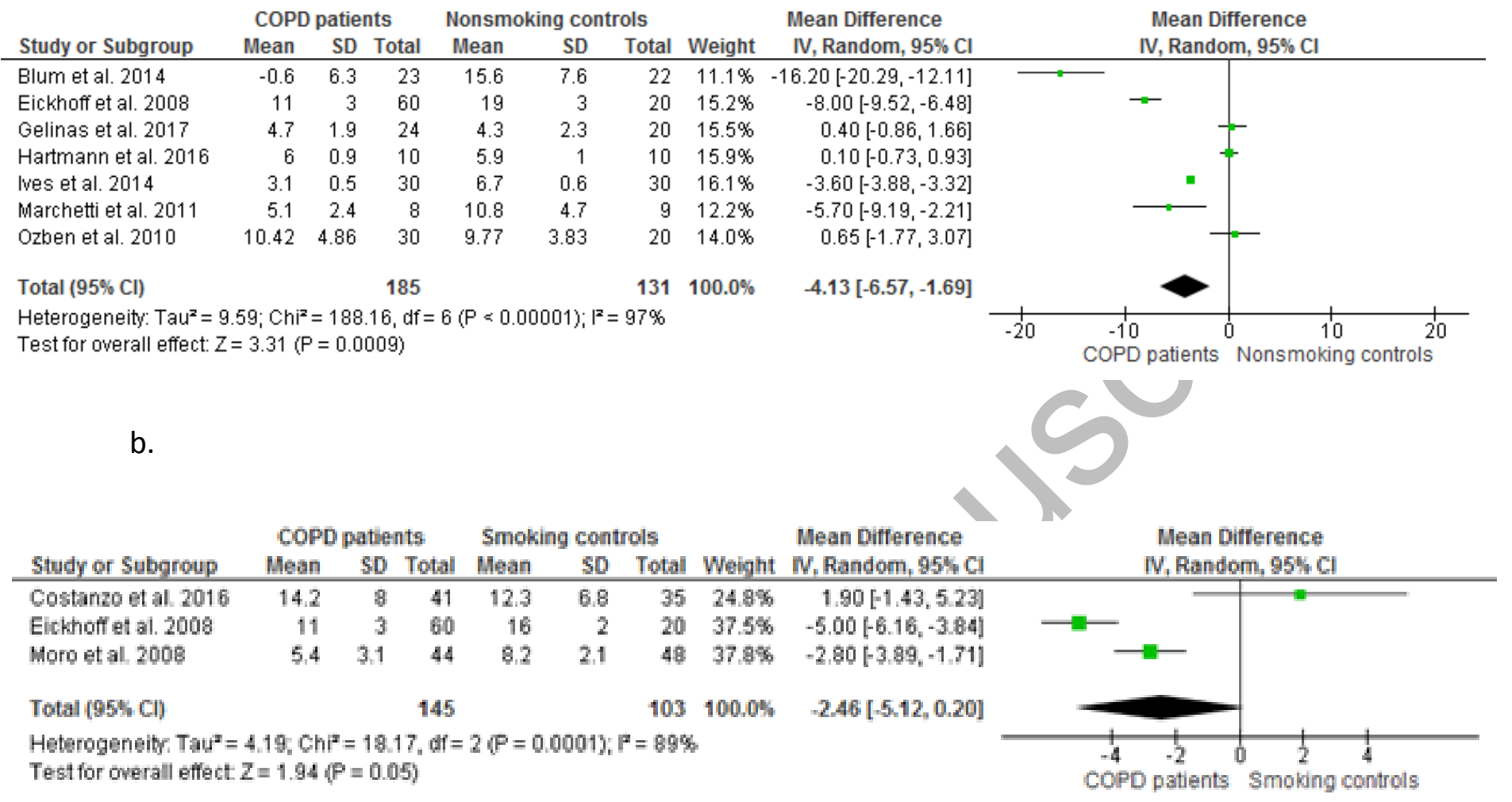

